\title{
Ribbed bedforms on palaeo-ice stream beds resemble regular patterns of basal shear stress ('traction ribs') inferred from modern ice streams
}

\author{
CHRIS R. STOKES, ${ }^{1}$ MARTIN MARGOLD, ${ }^{1 *}$ TIMOTHY T. CREYTS ${ }^{2}$ \\ ${ }^{1}$ Department of Geography, Durham University, Durham DH1 3LE, UK \\ ${ }^{2}$ Lamont-Doherty Earth Observatory of Columbia University, Palisades, NY, USA \\ Correspondence: Chris R. Stokes <c.r.stokes@durham.ac.uk>
}

\begin{abstract}
Rapidly-flowing ice streams are an important mechanism through which ice sheets lose mass, and much work has been focussed on elucidating the processes that increase or decrease their velocity. Recent work using standard inverse methods has inferred previously-unrecognised regular patterns of high basal shear stress ('sticky spots' $>200 \mathrm{kPa}$ ) beneath a number of ice streams in Antarctica and Greenland, termed 'traction ribs'. They appear at a scale intermediate between smaller ribbed moraines and much larger mega-ribs observed on palaeo-ice sheet beds, but it is unclear whether they have a topographic expression at the bed. Here, we report observations of riblike bedforms from DEMs along palaeo-ice stream beds in western Canada that resemble both the pattern and dimensions of traction ribs. Their identification suggests that traction ribs may have a topographic expression that lies between, and partly overlaps with, ribbed moraines and much larger mega-ribs. These intermediate-sized bedforms support the notion of a ribbed bedform continuum. Their formation remains conjectural, but our observations from palaeo-ice streams, coupled with those from modern ice masses, suggest they are related to wave-like instabilities occurring in the coupled flow of ice and till and modulated by subglacial meltwater drainage. Their form and pattern may also involve glaciotectonism of subglacial sediments.
\end{abstract}

KEYWORDS: ice sheet, ice stream, sticky spots, subglacial bedforms

\section{INTRODUCTION}

Ice sheets are drained by rapidly-flowing ice streams with tributaries of intermediate velocity that extend up to hundreds of $\mathrm{km}$ into their interiors (Bamber and others, 2000; Rignot and others, 2011). Towards the margins of an ice sheet, ice streams can become channelled within fjords and are referred to as 'outlet glaciers' (cf. Bentley, 1987). The large size (approximately one to tens of $\mathrm{km}$ wide; ten to hundreds of $\mathrm{km}$ long) and high-surface velocity (greater than hundreds of metres per year) of ice streams means they are an important mechanism through which ice sheets lose mass and contribute to sea level, and much work has been focussed on elucidating the mechanisms that facilitate their rapid flow (reviews by Bentley, 1987; Clarke, 1987; Bennett, 2003). An equally important and related question is: what slows them down? Part of the answer to this question, may lie with the recent discovery of a hitherto unrecognised but regular pattern of basal shear stress beneath modern ice streams (Sergienko and Hindmarsh, 2013; Sergienko and others, 2014). In this paper, we revisit some enigmatic bedforms on the now-exposed beds of palaeo-ice streams, which might be related to these phenomena and with the potential to provide additional insights regarding their formation.

Factors that increase basal shear stress are critically important because they can slow or even stop ice stream flow (Alley and others, 1994; Clark and Stokes, 2001;

* Present address: Department of Physical Geography, Stockholm University, Stockholm 106 91, Sweden.
Bougamont and others, 2003a, b; Christoffersen and Tulaczyk, 2003a, b, c; Stokes and others, 2007). However, the distribution of basal shear stresses and how they evolve through space and time is difficult to elucidate. Alley (1993) pointed out that the resistance offered by the bed is unlikely to be uniform, and discussed several lines of evidence from West Antarctic ice streams that were suggestive of localised areas of higher basal shear stress, which he termed 'sticky spots'. This evidence included ice surface rumples and crevassing (Vornberger and Whillans, 1986), spatially variable till thickness (e.g. Rooney and others, 1987) and inversions of basal drag calculated from ice velocity, elevation and thickness data (e.g. MacAyeal, 1992). Alley (1993) argued that sticky spots might be caused by a number of factors, such as bedrock bumps penetrating a layer of till and protruding into the base of an ice stream (MacAyeal, 1992; MacAyeal and others, 1995), discontinuities in the subglacial till layer (Rooney and others, 1987; Atre and Bentley, 1993; Smith, 1997) and raised regions of an ice stream's surface, which influence subglacial water flow (Bindschadler and others, 1987). Indeed, areas of well drained till can act as sticky spots (Anandakrishnan and Alley, 1994; Ashmore and others, 2014) and may be caused by diversion of subglacial water (Anandakrishnan and Alley, 1997) or by basal freeze-on (Bougamont and others, 2003a, b; Christoffersen and Tulaczyk, 2003a, b). Several of these types of sticky spots have also been inferred from palaeo-ice stream beds (Clark and Stokes, 2001; Knight, 2002; Christoffersen and Tulaczyk, 2003c; Piotrowski and others, 2004; Stokes and others, 2007, 2008; Graham 
and others, 2009; Trommelen and Ross, 2014; Trommelen and others, 2014) but, in general, there is a paucity of data on their distribution and evolution under both modern and palaeo-ice streams (review by Stokes and others, 2007).

Recently, two papers highlight previously-unrecognised regular patterns of high basal shear stress (sticky spots) beneath a number of Antarctic and Greenlandic ice streams (Sergienko and Hindmarsh, 2013; Sergienko and others, 2014). These studies utilised new high-resolution data on ice velocity, elevation and thickness to calculate basal shear stresses using standard inverse techniques based on control methods (MacAyeal, 1992). Although similar methods had shown alternating patches of a strong and weak bed beneath tributaries of the Siple Coast ice streams in West Antarctica (Joughin and others, 2004), the increased resolution of these inversions, compared with previous efforts, clearly revealed the presence of regular 'riblike' patterns of very high basal shear stress (typically 200-300 kPa; Fig. 1) embedded within much larger areas of near-zero basal shear stress in regions, where ice was assumed to be sliding across the bed. Importantly, the riblike patterns have a clear surface expression and are seen in the calculations of the driving dress, which is independent of the inversion technique, spatial resolution or its regularisation method.

Given the enigmatic nature of the features, they were informally referred to as 'traction ribs' by Sergienko and Hindmarsh (2013). They varied in size from several kilometres to tens of kilometres in length and a few kilometres wide, with the long axes aligned approximately transverse to ice flow, but often deviating by $\sim 30^{\circ}-60^{\circ}$ from the ice flow direction (Sergienko and Hindmarsh, 2013) (Fig. 1). Geometrical descriptions depend on the rib location, but these inversions of basal stresses show arcuate, generally transverse rib-like features, which are sometimes sinuous and show variations in width ( $b$-axis: typically parallel to ice flow direction) along their length (a-axis: typically perpendicular (transverse) to ice flow direction). The basal patterns are thinner than, and oblique to, the broadly corresponding expressions on the ice-sheet surface. They were found to be widespread throughout areas of slow and fast flow, but they were most pronounced in arcuate patterns within the onset zone of ice streams (Sergienko and others, 2014).

It is not clear what causes these regular patterns in basal shear stress, but Sergienko and Hindmarsh (2013) noted the correspondence between the traction ribs and areas of high hydraulic gradient, and suggested that subglacial water may play a role in rib formation. They suggested that the ribs are likely to be regions of variable effective pressure that cause localised strengthening along the base. Subglacial water flow between the overlying ice and underlying bed allows water to transfer between strong and weak bedded areas. However, the poor resolution of geophysical data over large areas of the bed is unable to reveal whether the ribs have a topographic expression at the bed, and/or whether they are related to an underlying geological control, such as bedrock bumps or ridges (also Joughin and others, 2004). Sergienko and Hindmarsh (2013) noted that their pattern, if not their dimensions, resembled subglacial bedforms observed on palaeo-ice sheet beds, such as the recently-discovered 'mega-ribs' (Fig. 2) reported by Greenwood and Kleman (2010), and the far more ubiquitous 'ribbed moraines' (Fig. 3), which have a longer history of investigation (reviews by Hättestrand, 1997; Hättestrand and Kleman, 1999; Dunlop and Clark, 2006a). Despite their similarity in pattern, however, Sergienko and others noted that both ribbed moraines and mega-ribs occur at different scales to the traction ribs. Here we report observations of rib-like bedforms from previously-identified palaeo-ice stream beds in western Canada (Evans and others, 1999, 2008, 2012, 2014; Evans, 2000; Ross and other, 2009; Ó Cofaigh and others, 2010) that appear to match both the pattern and dimension of the traction ribs and may therefore offer additional insights into their characteristics and formation.

\section{STUDY AREA AND PREVIOUS WORK}

As part of a larger project to identify the location of palaeoice streams in the North American Laurentide ice sheet (Margold and others, 2015a, b; Stokes and others, 2016), we reviewed the evidence for all previously hypothesised palaeo-ice streams, and searched for new ones by systematically inspecting a variety of satellite imagery and DEMs from both onshore and offshore areas. During this mapping, we found that several previously-identified ice stream beds in western Canada (Evans and others, 1999, 2008, 2014; Evans, 2000; Ross and other, 2009; Ó Cofaigh and others, 2010; Fig. 4) appear to be characterised by a topographic expression that bears close resemblance to the traction ribs reported by Sergienko and others. This topography is characterised by generally low-amplitude rib-like landforms that are generally aligned transverse to the ice stream flow direction (Fig. 5), but sometimes with obvious deviation.
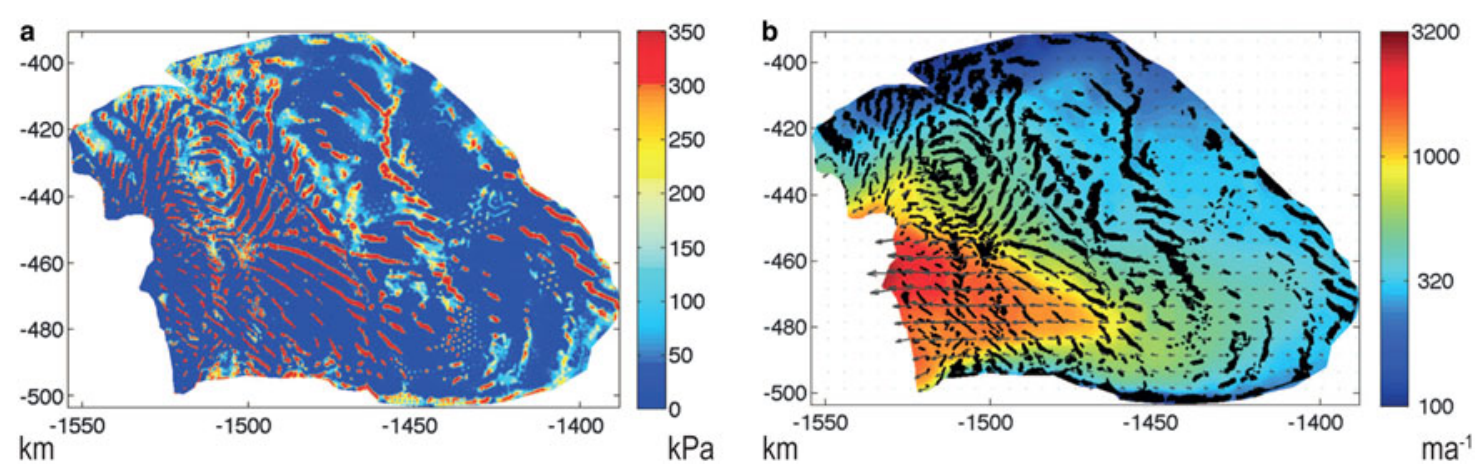

Fig. 1. (a) Inverted basal shear stress for Thwaites Glacier, West Antarctica (kPa), with ice flowing approximately right to left and $x$ - and $y$-axis $(\mathrm{km})$. (b) Observed ice surface speed $\left(\mathrm{m} \mathrm{a}^{-1}\right)$ with black patches showing rib-like patterns of basal shear stress $>100$ kPa and velocity vectors as grey arrows. Modified from Sergienko and Hindmarsh (2013). 


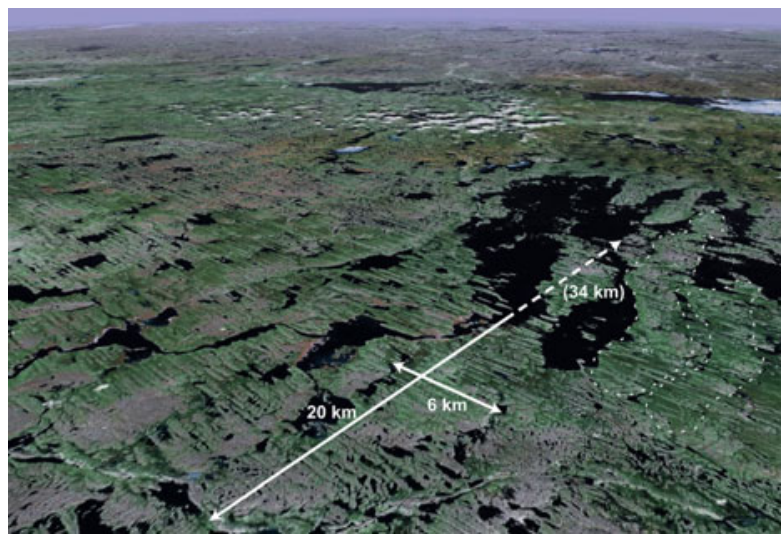

Fig. 2. Oblique view of Landsat image of mega-ribs discovered by Greenwood and Kleman (2010) north of Dubawnt Lake, Nunavut Territory, Canada (location marked as a small circle on Fig. 4a). These ribs form a repetitive sequence (dashed outlines) of large, but low amplitude $(5-10 \mathrm{~m})$ ridges that are superimposed with smaller drumlins and mega-scale glacial lineations formed by the late-glacial Dubawnt Lake palaeo-ice stream (Stokes and Clark, 2003). Ice flow direction bottom right to top left. Reproduced from Greenwood and Kleman (2010).

This topographic expression has been noted in previous work and is usually described as a series of 'large transverse ridges' (Evans and others, 1999, 2008), 'transverse bedforms' (Beaney and Shaw, 2000) or 'ripple interference patterns' (Ross and others, 2009). Given that 'pristine' thrust-block moraines are common throughout the study area in more

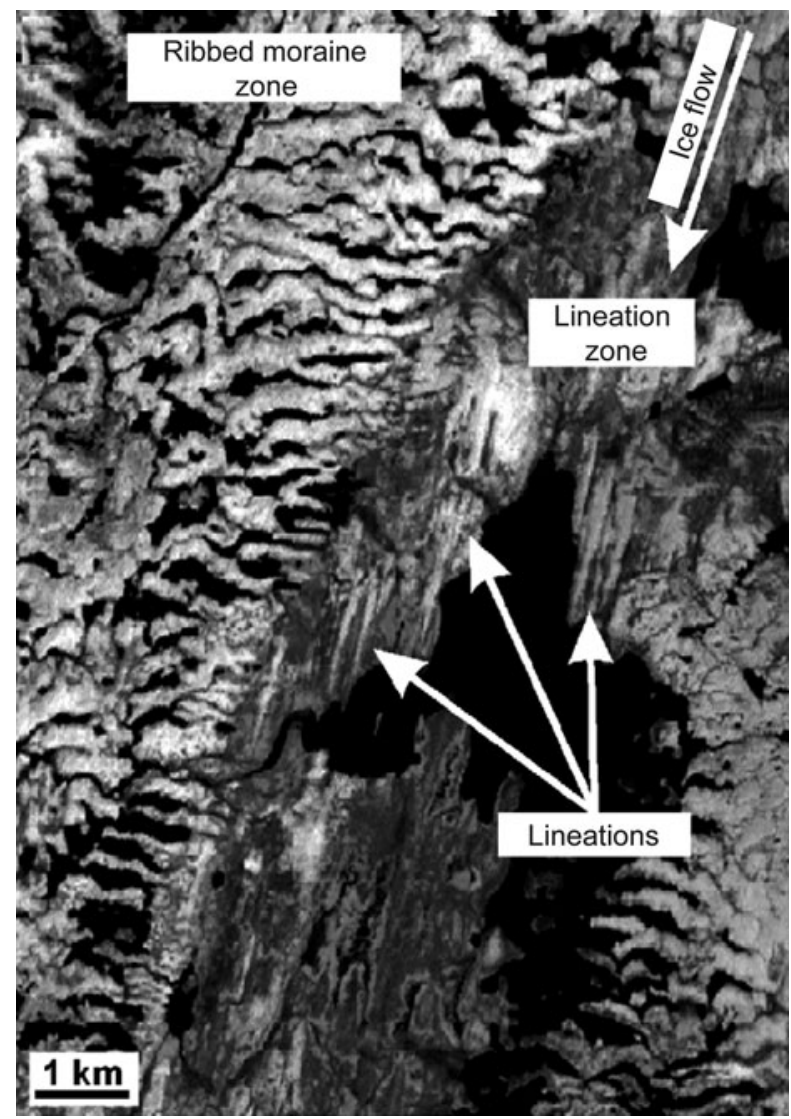

Fig. 3. Ribbed moraines in the Lac Naococane region, central Quebec, Canada (location marked as a small square on Fig. 4a). Ice flow direction from top to bottom. Figure modified from Dunlop and Clark (2006b). distal locations on the ice stream tracks (i.e. as ice marginal landform assemblages), the features are most commonly interpreted to reflect overridden thrust-block moraines within the main ice stream trunks (Evans and others, 1999, 2008, 2014; Evans, 2000). However, Beaney and Shaw (2000) invoked a more radical interpretation that they might represent giant ripples formed by standing waves in large subglacial meltwater flows. Furthermore, one unusual example from Manitoba, where the rib-like landforms are aligned much more parallel to ice flow direction, has been postulated to represent 'glacial curvileations' formed by longitudinal vortices in meltwater flow (Lesemann and others, 2010).

Field evidence for glaciotectonic disturbance within the ridges, including folding of both sediment packages and bedrock, has been reported in a number of studies (Evans and others, 1999, 2008, 2014; Evans, 2000). Evans and others $(2008,2014)$ also noted their preferential occurrence on the down-ice side of preglacial or buried valleys (i.e. on stoss slopes), which could also have induced glaciotectonism through compressive ice flow in these locations. Indeed, the low yield strength and high pore-water pressures of the weak Cretaceous bedrock that underlies much of the southern Interior Plains would have been particularly conducive to glaciotectonism (Evans and others, 2008, 2014). Moreover, they tend to occur in areas classified as a blanket of glacial sediments, and most commonly occur in sediment thicknesses ranging from 0 to $50 \mathrm{~m}$, but sometimes up to $200 \mathrm{~m}$ (Fig. 6). Evans and others (2008) also noted that glacial lineations (mega-flutings) can be seen emanating from the streamlined transverse ridges in several locations, providing further evidence for over-riding by fast-flowing ice.

Despite previous work noting their occurrence, there has been limited systematic mapping of the landforms across the Interior Plains that might allow quantitative comparisons with 'traction ribs' under modern ice masses. Thus, we revisited sites where they had been previously reported (Evans and others, 1999, 2008, 2012, 2014; Evans, 2000; Ross and others, 2009; Ó Cofaigh and others, 2010; Atkinson and others, 2014) and then surveyed the entire region of the southern Interior Plains (Fig. 4) to map their plan form and measure the morphology of the ridges.

\section{METHODS}

We searched a large area (Fig. 1b), but only identified rib-like bedforms on four different ice stream beds (Fig. 4b): (1) the Buffalo Ice Stream; (2) the Central Alberta Ice Stream, (3) the James Lobe and (4) the Red River Lobe. We used the Shuttle Radar Topography Mission (SRTM) Digital Elevation Data (SRTM, 2015) to identify and map the rib-like landforms. The DEM has a spatial resolution of one arc second and permitted the identification and mapping of the ridges with greater accuracy than other DEMs that we tested (including freely-available Canadian Digital Elevation Data and the ASTER GDEM). SRTM data tiles were displayed in ArcGIS and individual ridges ('ribs') were digitised as polygons around their break-of slope. We extracted the length (a-axis) of each ridge automatically using the 'Minimum Bounding Geometry' tool in ArcGIS and then used topographic profiles to measure their width, wavelength and amplitude at two sites where the ridges appear to be best-preserved and most closely resembling the scale and pattern of traction ribs from modern ice masses. We also measured the 


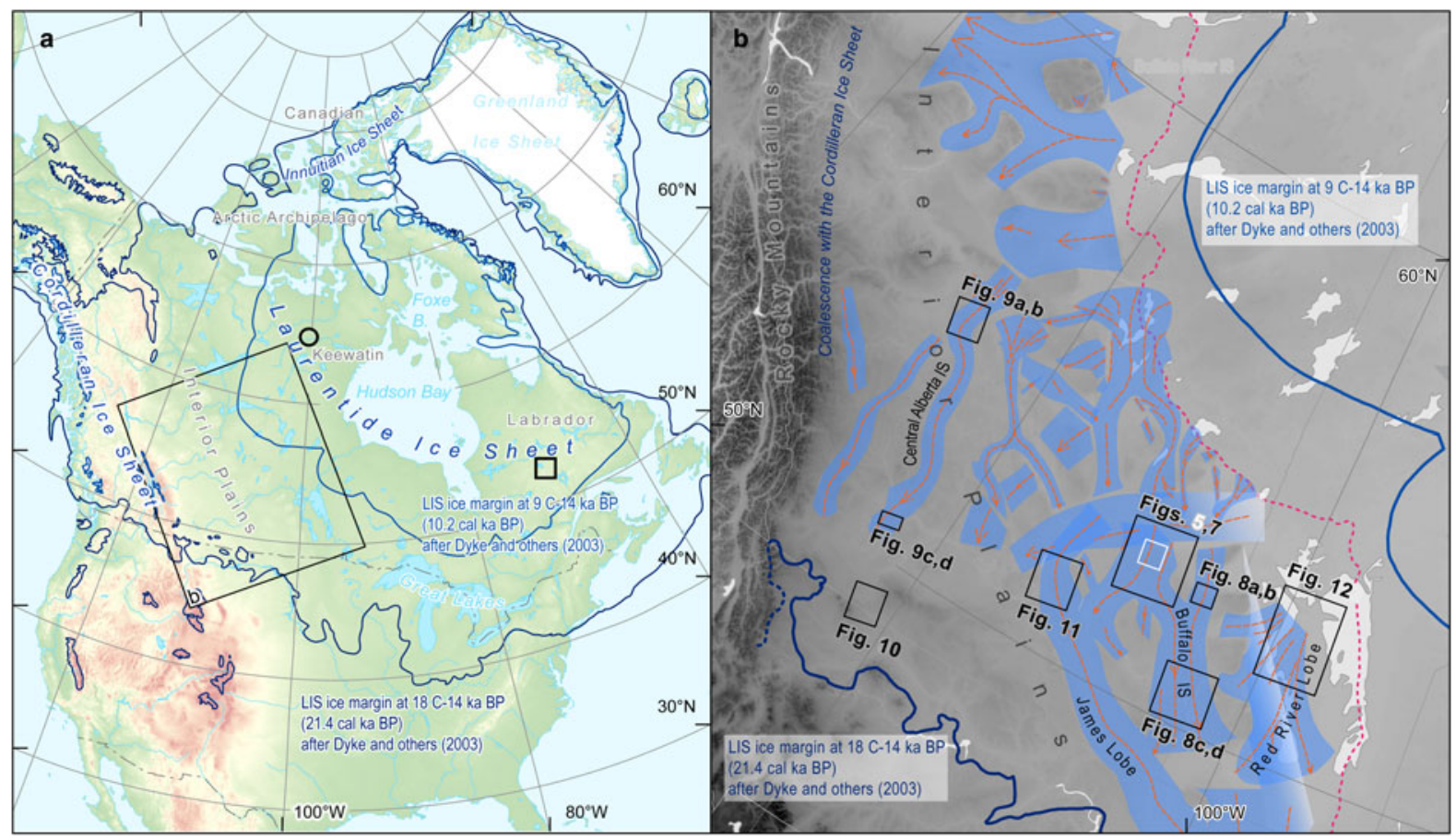

Fig. 4. (a) The location of the study area (black rectangle) in relation to the extent of the North American Ice Sheet Complex at 21.4 ka (blue curve) and $10.2 \mathrm{ka}$ (purple curve). The location of the features in Figure 2 (black circle) and Figure 3 (black square) are also shown. (b) Closeup of the study area showing previously-reported palaeo-ice stream tracks at the western and south-western margin of the Laurentide ice sheet drawn in blue (after Margold and others, 2015a). The location of Figures 5, 7-12 are marked. Note that the palaeo-ice streams did not operate at the same time, which explains their cross-cutting relationship (e.g. see Ross and others, 2009; Ó Cofaigh and others, 2010; and reviewed in Margold and others, 2015b). The dashed red curve in (b) is the boundary of the Canadian Shield.

deviation of the long-axis of each ridge from the predominant ice flow direction, which is inferred from independent evidence such as nearby glacial lineations (drumlins and mega-scale glacial lineations) and lateral shear margin moraines. Indeed, in all cases, the ice streams appear to have formed distinct corridors characterised by smoothed terrain with sharp transitions to the adjacent landscape unaffected by fast ice flow, and this gives a good indication of the ice flow direction along the central axis of each ice stream (often with glacial lineations aligned parallel to the trough margins: cf. Evans and others, 1999, 2008, 2014; Evans, 2000; Ross and other, 2009; Ó Cofaigh and others, 2010; Margold and others, 2015a). However, local variations in ice stream flow commonly occur within modern-day ice streams (i.e. convergence and divergence; $\mathrm{Ng}, 2015$ ) and these might, in places, introduce uncertainty in our estimates of how much the rib-like ridges deviate from ice flow direction. In addition, we acknowledge uncertainty due to the possibility of lateral migrations of the ice stream margins and changing ice flow configurations through time (Ross and others, 2009).

Using the GTOPO30 DEM, we also carried out a slope and aspect analysis of the sites where the ribbed landforms were mapped. This DEM has a spatial resolution of 30 $\operatorname{arcsec}(\sim 1 \mathrm{~km})$ and is thus more suitable for a broad-scale terrain analysis, filtering out higher topographic detail such as the ribs themselves. Analysis of slope and aspect were undertaken using in-built functions in ArcMap software. Note that these analyses did not take isostatic depression into account, but it is likely to have had a regional effect of overdeepening the study area (Fig. 4b) and causing steeper slopes towards the ice sheet's interior (towards the NW), rather than a localised effect on different ice stream beds.
We also obtained data on surficial geology (Geological Survey of Canada, 2014), drift thickness (Fenton and others, 1994) and bedrock geology (Garrity and Soller, 2009), which we compared with the distribution of ridges (see Fig. 6).

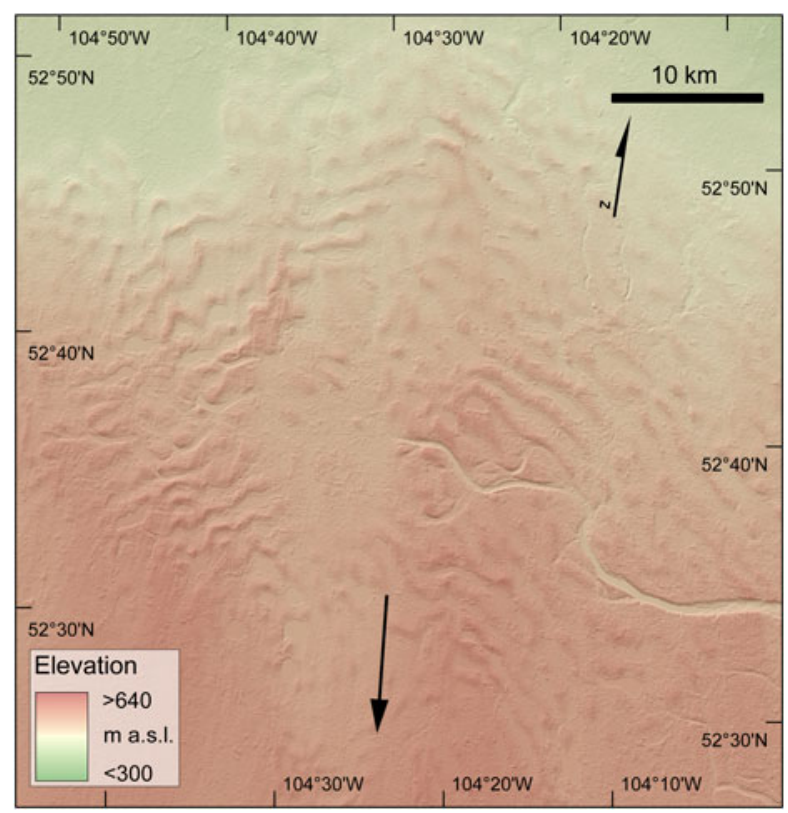

Fig. 5. Example of a cluster of low amplitude rib-like ridges generally aligned transverse to the ice stream flow direction (black arrow) on the Buffalo Ice Stream corridor (Ross and others, 2009), Saskatchewan (see also Fig. 7). These ridges are similar in scale and pattern to the traction ribs (Fig. 1) identified by Sergienko and Hindmarsh (2013) and Sergienko and others (2014). 


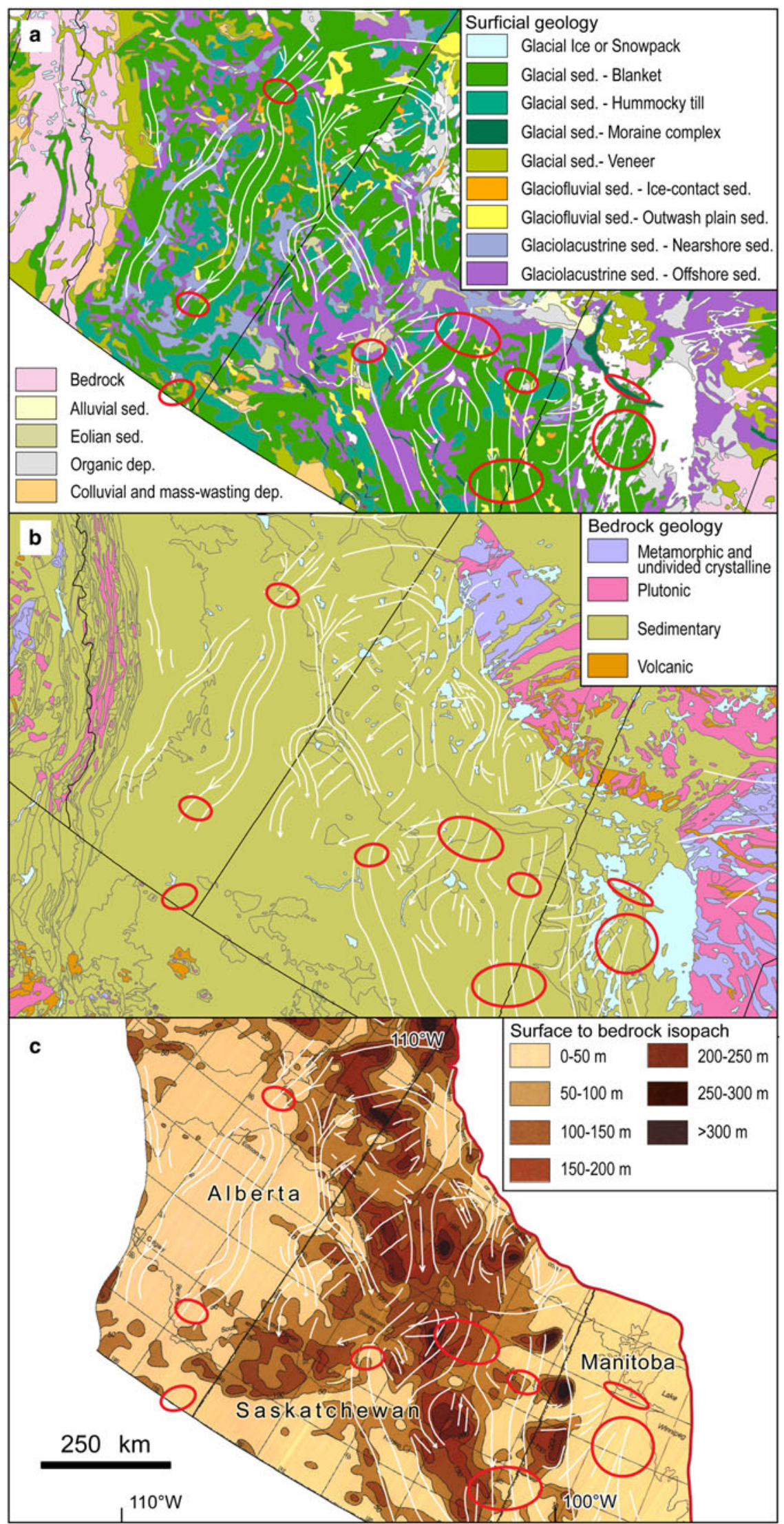

Fig. 6. Correspondence between the broad-scale location of mapped ribbed bedforms and (a) surficial geology, (b) bedrock geology and (c) till thickness. (a) Surficial geology from Geological Survey of Canada (2014). (b) Bedrock geology adapted from Garrity and Soller (2009). (c) Drift thickness (m) adapted from Fenton and others (1994). Reconstructed ice stream tracks (after Margold and others, 2015a) are drawn in white (locations on Fig. 4b) and the sites with mapped ribbed features are depicted in red ovals. The boundary of the Canadian Shield is marked by a dark red curve on the eastern edge of the figure in (c). 


\section{RESULTS}

In total, we mapped 1478 individual ridges ('ribs') in nine locations on four different ice stream beds. We now briefly describe the characteristics of the ridges in each setting and Tables 1, 2 detail their morphometric data. These rib-like landforms tend to be approximately transverse to the general direction of ice flow, but can show marked deviations. Their closed form ranges from nearly circular to elongate and some show a higher degree of sinuosity. Generally, they are longer than wide and their appearance resembles rib-like patterns. Thus, below, we use the non-genetic term 'rib-like' ridges to describe these features. This is also consistent with Sergienko and Hindmarsh (2013) and Sergienko and others (2014)

Some of the best-developed rib-like ridges (Figs 5, 7) occur in the upstream (northern) portion of the Buffalo Ice Stream (Ross and others, 2009; Margold and others, 2015a, b). The ice stream track is characterised by a much smoother terrain than the surrounding landscape and the ridges are mostly clustered on an adverse slope (i.e. where the ice stream flowed uphill over relatively low slopes; Fig. 7d). In places, flow-aligned glacial lineations are seen upstream and downstream of the traction ribs and may exist beneath them, albeit with more uncertainty. In general, the ridges are aligned oblique to ice flow direction along the central axis of the ice stream, but can be seen to almost align with the ice flow direction and merge with the orientation of glacial lineations in some regions. Their mean length is $3134 \mathrm{~m}(n=340)$ and their mean deviation from the general ice flow direction is $46^{\circ}$. Topographic transects across the ridges (Figs $7 \mathrm{~b}, \mathrm{c}$ ) indicate a mean width of $1052 \mathrm{~m}$, a mean wavelength (crest-crest spacing) of 1914 $\mathrm{m}$ and a mean height of $18 \mathrm{~m}$.

In the eastern branch of the Buffalo Ice Stream, a further set of ribbed landforms occurs in an identical topographic setting to the one described above: the ribs occur on an adverse slope, forming a pattern with a-axes oriented oblique to the ice flow direction (Figs $8 a-d$ ). At this site, the mean length of the ridges is $1837 \mathrm{~m}$ and their mean deviation from the ice flow direction is $28^{\circ}$. Further south on the Buffalo Ice Stream, a smaller number of ridges occur that are clustered on the stoss side of some slightly higher elevation areas (Figs 8e, f). Their mean length is $2089 \mathrm{~m}$ and their mean deviation from ice flow direction is $59^{\circ}$.

Three zones of ridges are also mapped on the Central Alberta Ice Stream track (Evans, 2000; Evans and others, 2008, 2012, 2014; Ross and others, 2009). Similar to the Buffalo Ice Stream corridor, a cluster of features is associated with the stoss side of an area of elevated terrain where the ice stream was forced to flow uphill (Figs 9a, b). There are fewer ridges in this region, but their lengths (mean $=2154 \mathrm{~m}$ ) are comparable with the Buffalo Ice Stream, and they also deviate from ice stream flow to a similar extent $\left(\right.$ mean $\left.=48^{\circ}\right)$.

Further downstream, 36 ridges are mapped. These are slightly shorter (mean: $1302 \mathrm{~m}$ ) and aligned approximately perpendicular to ice stream flow direction (mean deviation: $67^{\circ}$ ) (Figs 9c, d). At the southernmost limit of the ice stream (Evans and others, 2008), we map another series of ridges $(n=187)$ in the Milk River area (Fig. 10), close to the US-Canadian border (Fig. 4b). This location is not on a previously-hypothesised ice stream trunk, but is located directly downstream of the distal end of the Central Alberta Ice Stream and is likely to have been subjected to a period 


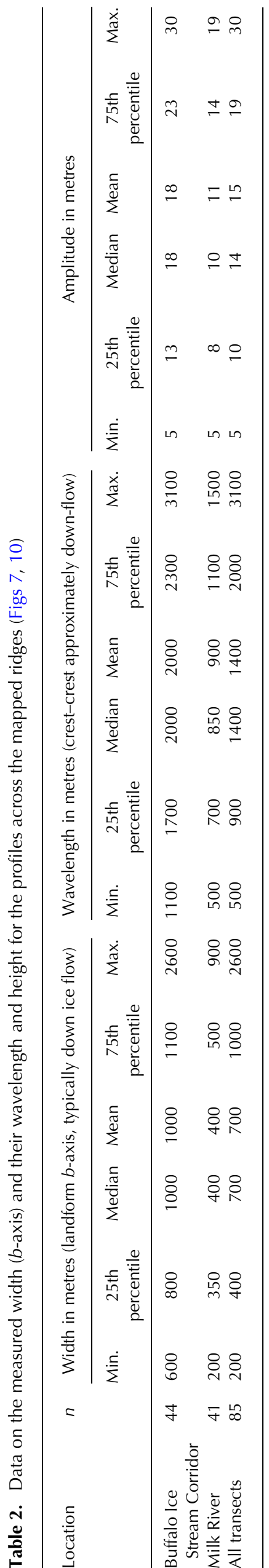

of fast ice flow during the maximum extent of the ice sheet in this region (Evans and others, 2008). The ridges in this location are very similar to those elsewhere in the study area, with a mean length of 1960 and with a deviation of $61^{\circ}$ from the ice stream flow direction. The data on width, wavelength and height averaged from three transects drawn approximately parallel to the ice flow direction and aligned with the $b$ axis of the landforms in this locality (means of 417, 920, and $11 \mathrm{~m}$, respectively; Fig. 10c), indicate that the ribbed landforms here are generally smaller than the ribbed landforms measured in the upper portion of the Buffalo Ice Stream. As in other areas, the Milk River site displays a clear association between the ridges and an elevated area of the ice stream bed (Beaney and Shaw, 2000), although they are not necessarily more prevalent on the stoss side in this location.

The upstream portion of the James Lobe (Clayton and others, 1985; Clark, 1992; Patterson, 1997; Ross and others, 2009) also contains a series of ridges $(n=96)$ on the stoss side of higher ground that crosses the ice stream track (Fig. 11), with a mean length of $2311 \mathrm{~m}$, and a mean deviation from ice stream flow of $56^{\circ}$.

Finally, we map two clusters of rather different ridges in the Red River Lobe (Fig. 12). On the overridden Pas Moraine (Dyke and Dredge, 1989) are a small number $(n=38)$ of ridges that have a mean length of $3080 \mathrm{~m}$ and a mean deviation from ice stream flow of $52^{\circ}$. To the south lies a much larger cluster of longer ridges covering $6800 \mathrm{~km}^{2}$, with a mean length of $4764 \mathrm{~m}$. Interestingly, these ridges (the longest we report) appear to be more closely aligned with the ice flow direction (although still oblique), with a mean deviation of only $20^{\circ}$. They have also been described as 'glacial curvilineations' (Lesemann and others, 2010) and, while the general appearance resembles the features that we map elsewhere, their orientation with respect to ice flow direction is different in being much nearer to parallel. While this example is perhaps not as clear as the other examples, it is impossible to completely eliminate it without more detailed, site-specific information (e.g. field data). Furthermore, we note that ribs of a similar orientation are seen in the inversion from modern ice masses (e.g. see Bindschadler Ice Stream, West Antarctica: Fig. 2 in Sergienko and others, 2014).

To summarise, we mapped 1478 individual ridges spread across nine locations that range in area from 150 to 6800 $\mathrm{km}^{2}$. Rib-like ridges are found in both upstream and downstream locations and typically occur in association with elevated areas of the ice stream bed and commonly (although not always) on adverse slopes with ridge a-axes aligned locally parallel to the slope contours. Their lengths, widths, amplitudes and wavelengths are similar (Fig. 13; Tables 1, 2 ); and they are typically found to deviate from ice flow direction between $45^{\circ}$ and $70^{\circ}$, apart from one case (Fig. 12), in which they are more closely aligned.

\section{DISCUSSION}

\subsection{Comparison between 'traction ribs' and rib-like ridges on palaeo-ice streams}

Sergienko and Hindmarsh (2013) and Sergienko and others (2014) noted the similarity in form and pattern between the 'traction ribs' they identified beneath modern ice streams and ribbed landforms that have been reported on palaeoice sheet beds. However, they also noted that the scale of 


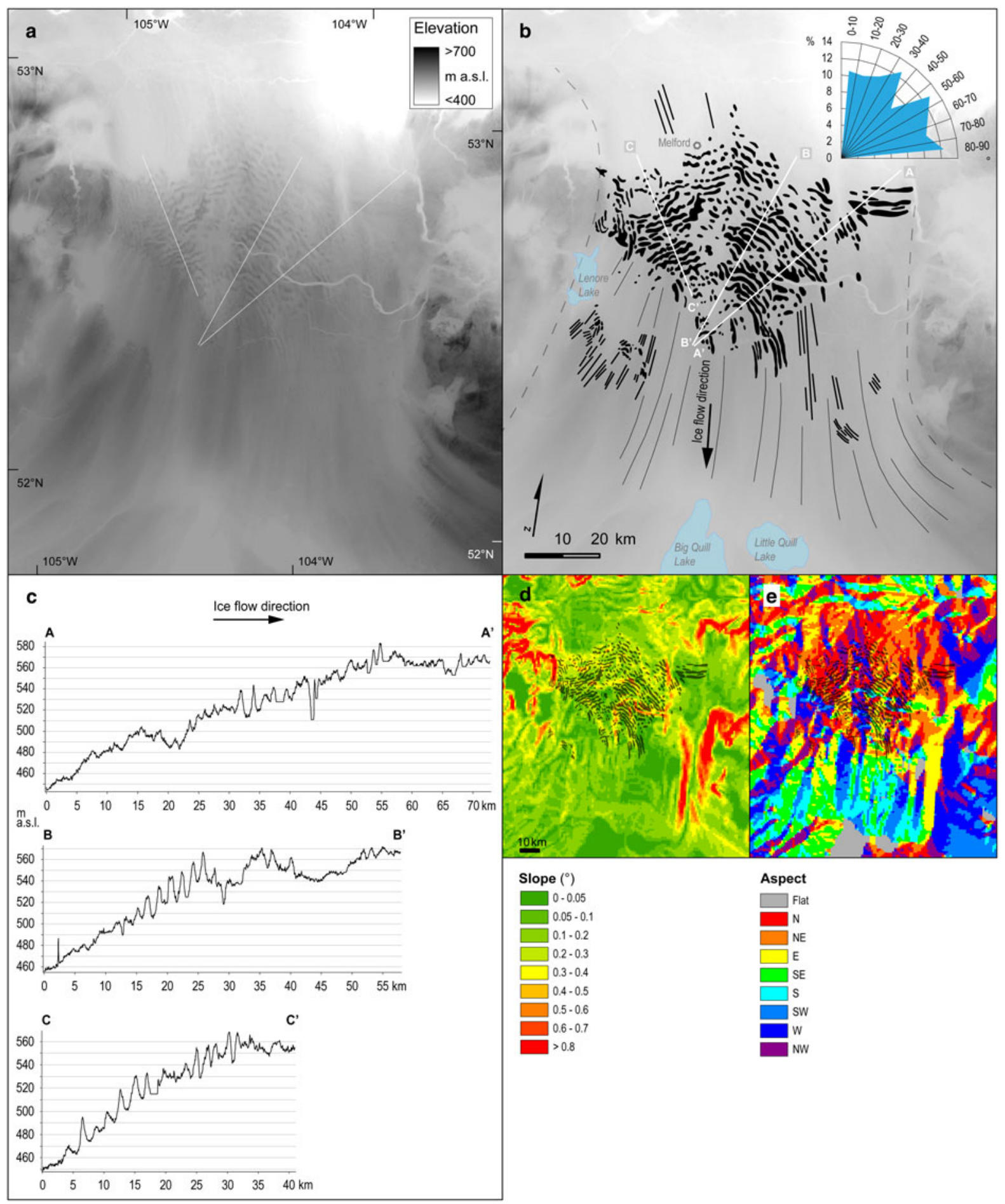

Fig. 7. (a) SRTM DEM of the upstream portion of the Buffalo Ice Stream corridor (ice stream flow from north to south: location shown on Fig. 4). (b) Mapped ridges (black polygons) and selected glacial lineations (black curves) showing ice stream flow direction, with dashed curves showing approximate location of ice stream lateral margins. The distribution of the ridge a-axis deviation from ice flow direction is also plotted. (c) Topographic profiles across the mapped ridges (location shown on (b)). Note that the profiles are not all draw along-flow, but are aligned to extract the $b$-axis (width) of each of the ridges. (d), (e) Ribbed features overlain on a slope and aspect map, respectively.

the 'traction ribs' appeared to lie in between previouslyreported landforms. The mega-ribs reported by Greenwood and Kleman (2010) are typically longer (a-axes transverse to flow: $20-40 \mathrm{~km}$ ) and wider (b-axes parallel to ice flow: 3-6 km) (Fig. 2), and their orientation is more consistently aligned perpendicular to the inferred direction of ice flow. Sergienko and Hindmarsh (2013) also noted that the relatively subdued amplitude of mega-ribs (reported as 5-10 m in Greenwood and Kleman, 2010) would be difficult to detect beneath thick ice. In contrast, although ribbed moraines appear in a variety of forms and patterns (Hättestrand and Kleman, 1999; Dunlop and Clark, 2006a; Trommelen and others, 2014), they are generally much smaller than the traction ribs reported by Sergienko and others, with typical lengths of hundreds of metres to a few kilometres, and widths of just a few hundred metres (Dunlop and Clark, 2006a, b) (Fig. 3). They are also spaced much closer together (of the order of a few hundred metres) and, again, their long 


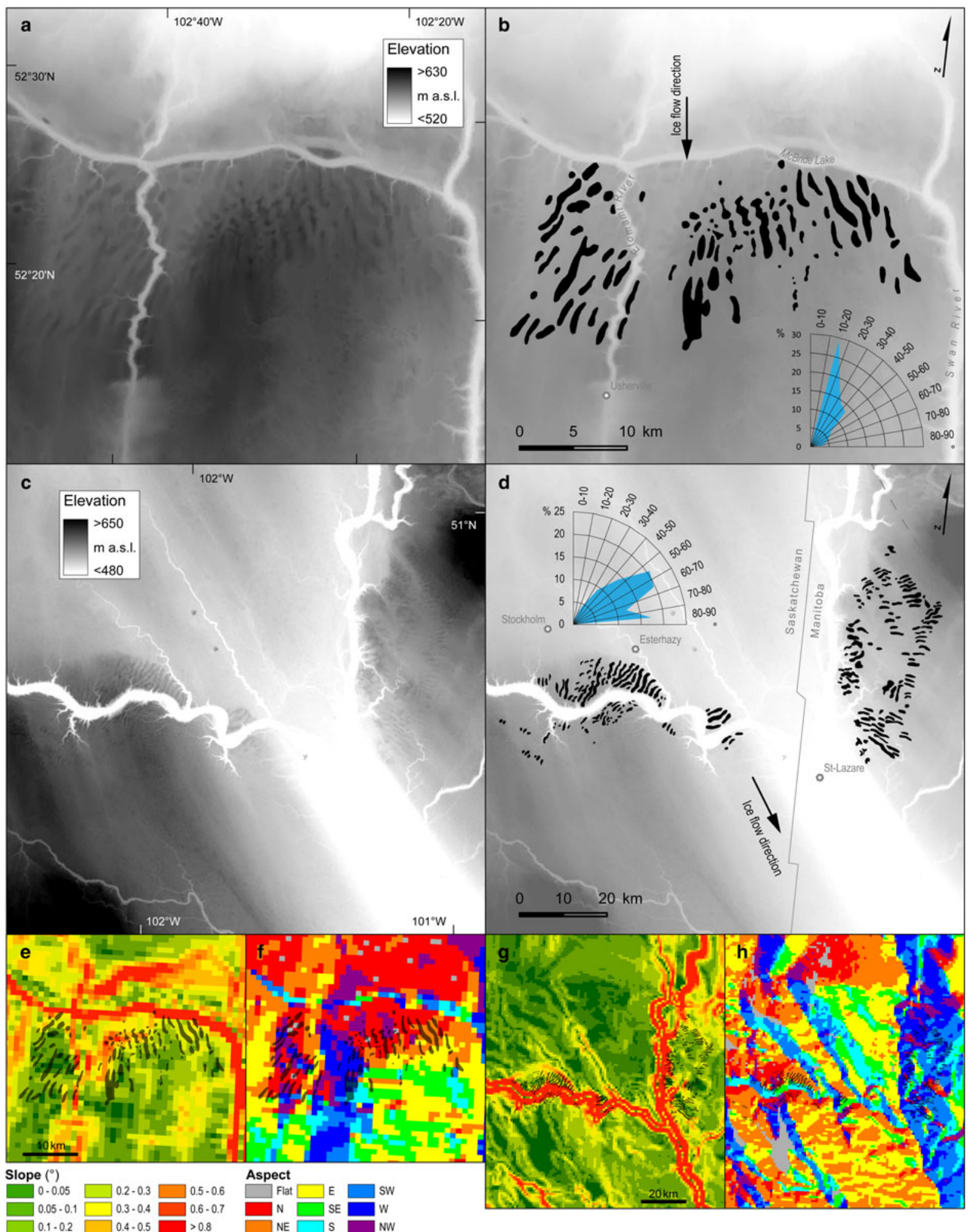

Fig. 8. (a) SRTM DEM of the eastern branch of portion of the Buffalo Ice Stream corridor (ice stream flow from north to south: location shown on Fig. 4). (b) Mapped ribbed features (black shapes) and the deviation of ridge a-axis orientations from the ice flow direction. (c) SRTM DEM of the southern portion of the Buffalo Ice Stream corridor (ice stream flow from north-west to south-east; location shown on Fig. 4). (d) Mapped ribbed features (black shapes) and the deviation of ridge a-axis orientations from the ice flow direction. Note that the timing of incision of the large channels that cut across the area is not known (they host an under-sized modern stream), but they likely originate from the period of deglaciation and formed after the formation of the ridges. The location of the ribbed features in relation to slope and aspect are shown in (e-h).

axes are typically perpendicular to the inferred ice flow direction (Fig. 3), rather than oblique.

The ridges we report in this paper (Figs 5, 7-12) exhibit similar dimensions to those reported by Sergienko and
Hindmarsh (2013). Their lengths (interquartile range: 1.2$3.6 \mathrm{~km}$; Fig. 13) are slightly lower than the mean value of $\sim 6 \mathrm{~km}$ reported by Sergienko and Hindmarsh (2013), but their mean widths $(0.4-1 \mathrm{~km})$ are much closer to the traction 


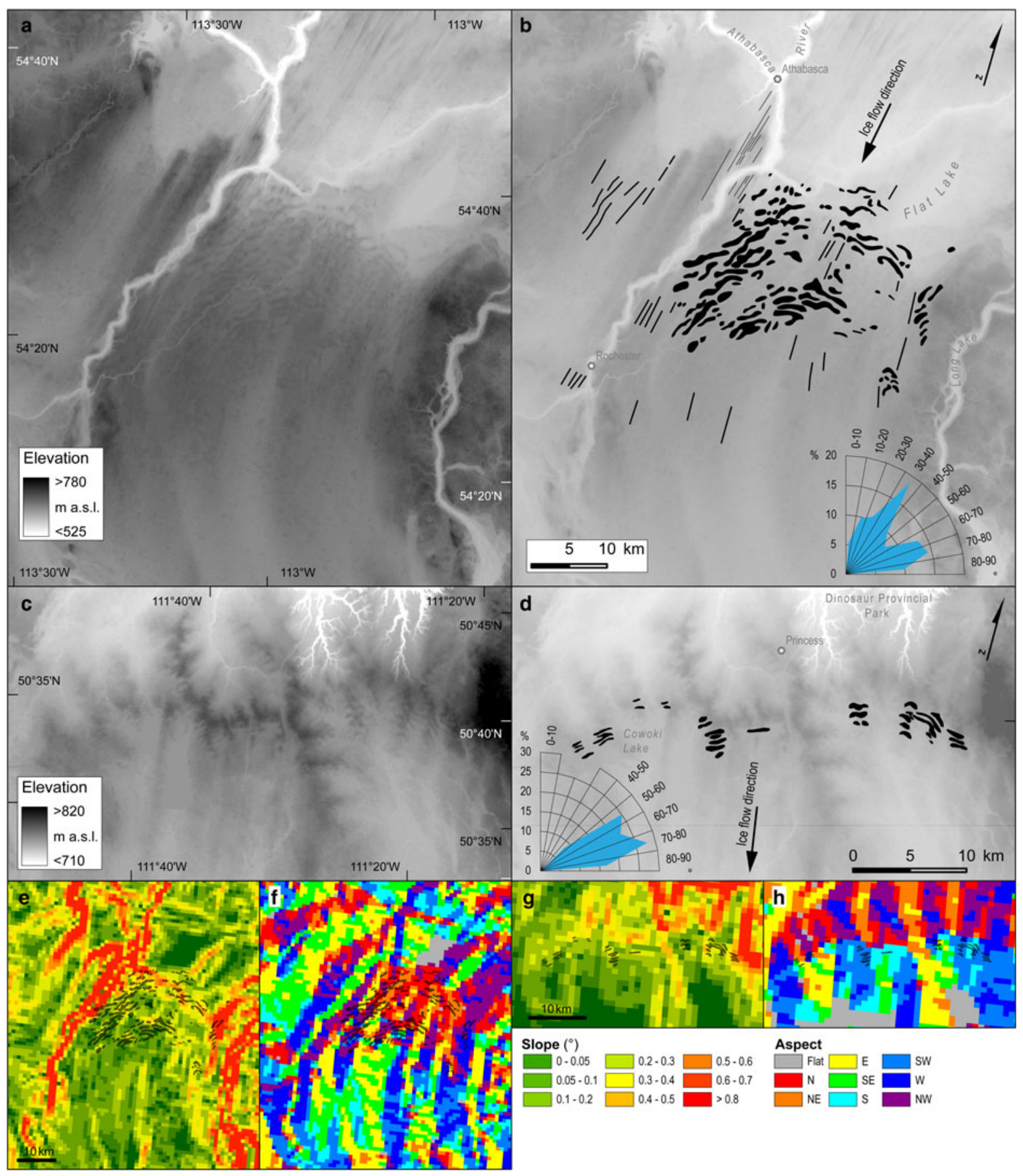

Fig. 9. (a) SRTM DEM of the upstream portion of the Central Alberta Ice Stream (ice flow from north-east and then bends towards the south; location shown on Fig. 4). (b) Mapped ribbed features (black shapes) and selected glacial lineations (black lines), along with the distribution of traction ribs a-axis deviation from ice flow direction. (c) SRTM DEM of the downstream portion of the Central Alberta Ice Stream (ice flow from north to south; location shown on Fig. 4). (d) Mapped ribbed features (black shapes), along with the distribution of ridge a-axis deviation from ice flow direction. The location of the ribbed features in relation to slope and aspect are shown in (e-h).

ribs under modern ice streams. Their wavelengths $(\sim 0.9-2$ km; Fig. 13) are also similar to most of the patterns reported by Sergienko and others, but towards the lower end of their mean value of $6.5 \mathrm{~km}$ (Sergienko and Hindmarsh, 2013). Unlike mega ribs and ribbed moraines, we also note that many of the ribbed features we mapped are aligned obliquely to ice flow direction at angles of $\sim 20^{\circ}-70^{\circ}$ (Fig. 13) and mimic the arcuate patterns of ribs reported by Sergienko and others. Profiles across the ridges indicate that they have amplitudes of 10-19 m, which is higher than megaribs (Greenwood and Kleman, 2010), but slightly lower than the mean value for a large sample of ribbed moraines (17 $\mathrm{m}$ in Dunlop and Clark, 2006a). Thus, the ridges we observe appear to represent an intermediate scale of ribbed landform that overlaps with the more extreme (larger) upper dimensions of ribbed moraine (Fig. 3) and the lower dimensions of mega-ribs (Fig. 2). This can be clearly seen when traction ribs are compared - at the same scale - with mega-ribs, ribbed moraine and the ridges we report in this paper (Fig. 14). We therefore suggest that the ridges we have mapped may be related to the 'traction ribs' identified from inverse methods on modern ice masses (Sergienko 


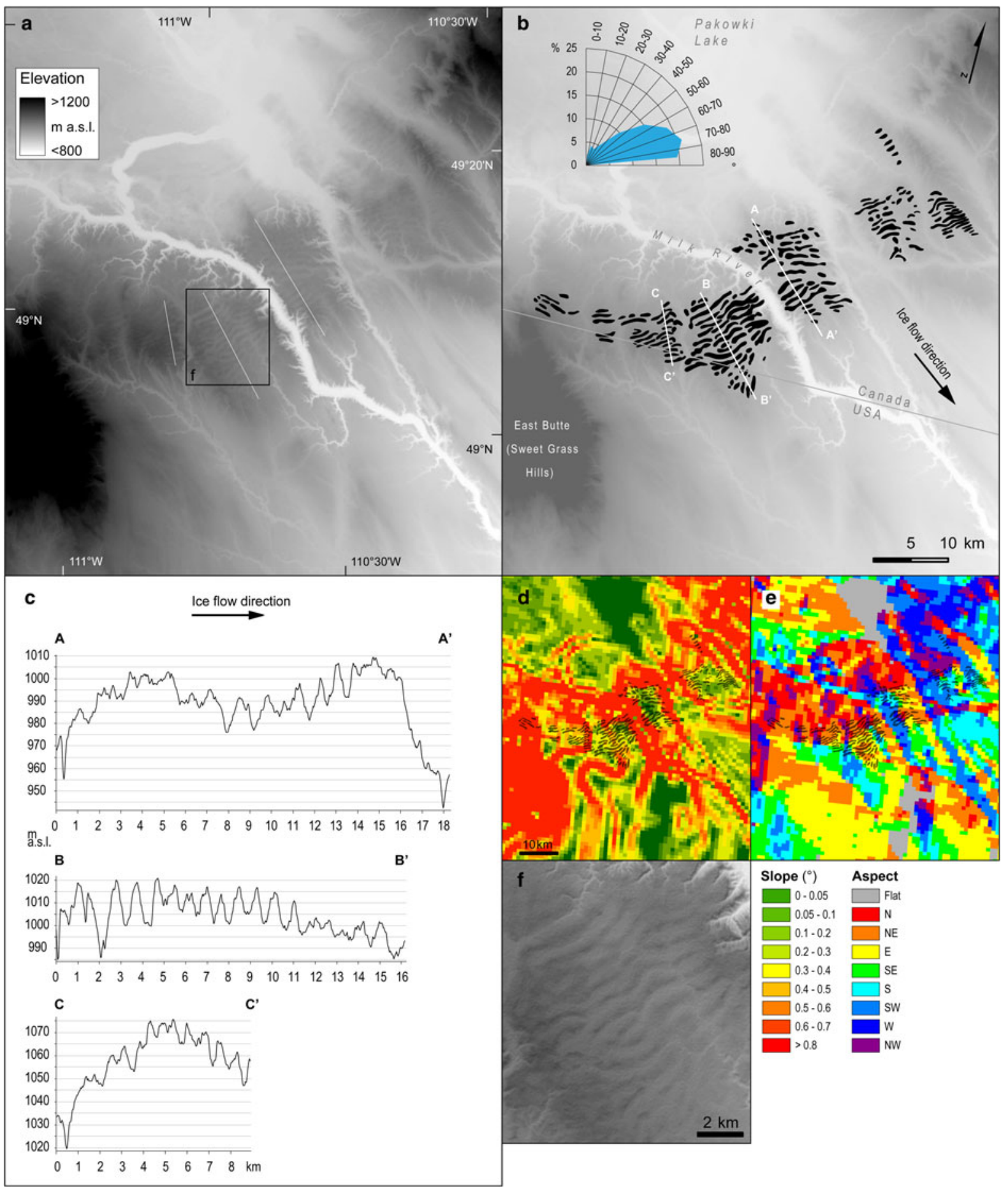

Fig. 10. (a) SRTM DEM of the distal portions of the Central Alberta Ice Stream (Evans and others, 2008) near the Milk River close to the USCanadian border (ice flow from north-west to south-east: location shown on Fig. 4). (b) Mapped ribbed features (black shapes), along with the distribution of ridge a-axis deviation from ice flow direction. (c) Topographic profiles across the mapped pattern of ridges (location shown on (b)). (d), (e) Ribbed features overlain on a slope and aspect map, respectively. (f) Close-up of the ridges shown in (a).

and Hindmarsh, 2013; Sergienko and others, 2014). This is an unusual example of features inferred from beneath modern ice masses subsequently being identified on a palaeo-ice sheet bed (rather than the other way around).

\subsection{Formation of ribbed features on ice stream beds}

If the features we observe are related to the traction ribs from under modern ice masses, they may provide additional insight into their formation. Observations of both modern and palaeo-ice stream beds (e.g. King and others, 2009;
Spagnolo and others, 2014) indicate that where till is present in sufficient thickness, it is usually shaped into a corrugated surface of highly elongated ridges and grooves that are aligned parallel, rather than oblique, to ice flow direction. Rib-like landforms have only rarely been reported on palaeoice stream beds and these have usually been much smaller ribbed moraines and have been interpreted to reflect higher basal shear stresses and/or ice stream sticky spots (Dyke and Morris, 1988; Stokes and others, 2007, 2008; Trommelen and Ross, 2014). However, there is little consensus as to their precise mechanisms of formation. Some view 


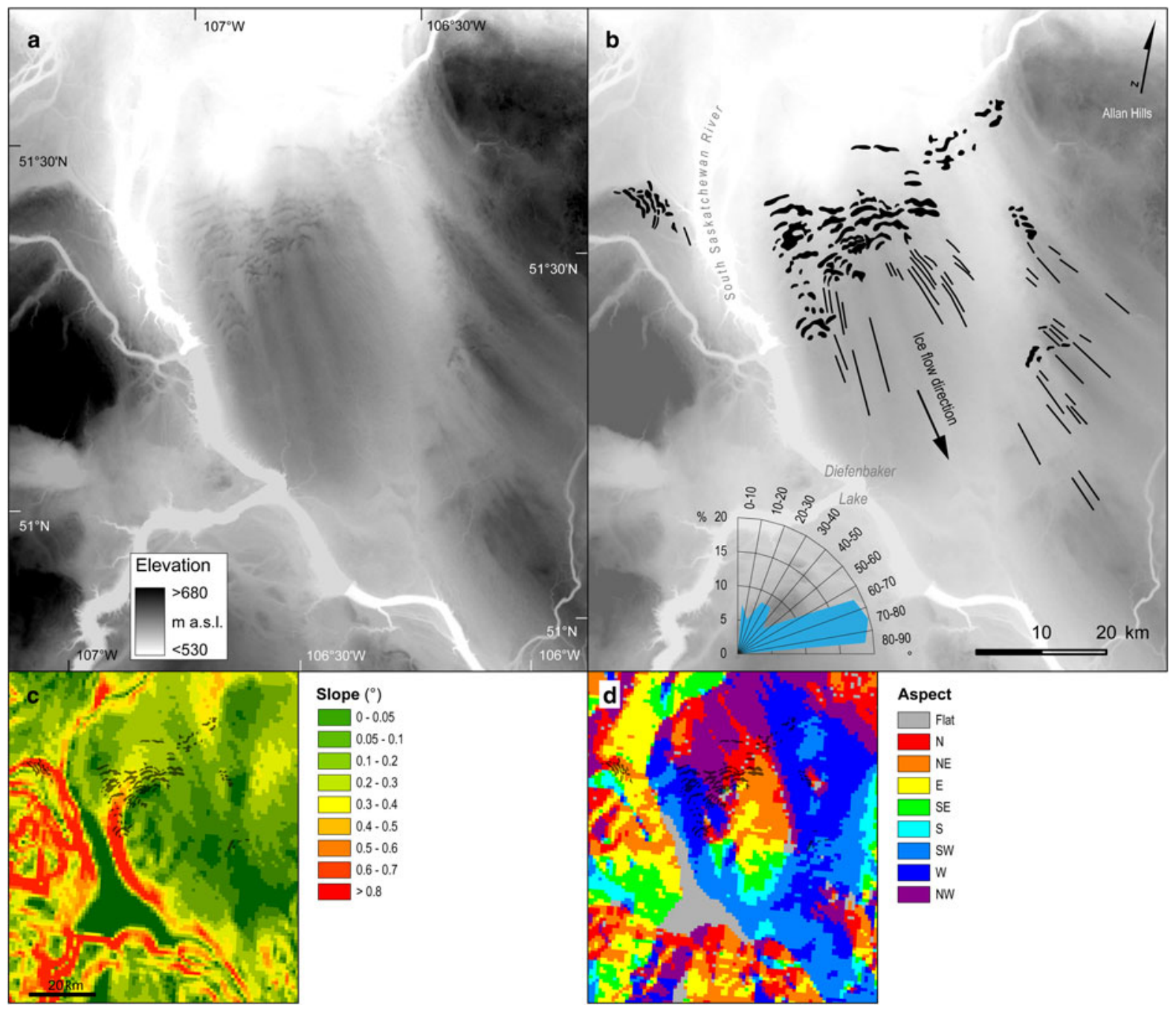

Fig. 11. (a) SRTM DEM of the upstream portion of the James Lobe (ice flow approximately from north to south-east; location shown on Fig. 4). (b) Mapped ribbed features (black polygons) and selected glacial lineations (black lines), along with the distribution of ridge a-axis deviation from ice flow direction. Note that the glacial lineations in this case show that there may have been some subtle (up to $10^{\circ}-20^{\circ}$ ) shift in flow direction. (c), (d) Ribbed features overlain on a slope and aspect map, respectively.

ribbed moraines as polygenetic landforms with separate stages of development that might involve ice flow reshaping pre-existing ridges, moraines, or even drumlins (e.g. Boulton, 1987; Lundqvist, 1989, 1997; Möller, 2006). Others have sought specific mechanisms that are not reliant on pre-existing ridges and these can be grouped into four main categories: (1) glaciotectonic shearing and stacking (e.g. Shaw, 1979; Aylsworth and Shilts, 1989; Bouchard, 1989); (2) fracturing and extension of frozen till sheets (Hättestrand, 1997; Hättestrand and Kleman, 1999); (3) subglacial meltwater floods (Fisher and Shaw, 1992; Beaney and Shaw, 2000), and (4) an instability in the coupled flow of ice and till (Dunlop and others, 2008; Chapwanya and others, 2011).

As noted in Section 2, the rib-like features that we report have mostly been interpreted as overridden thrust-block moraines (Evans and others, 1999, 2008, 2014; Evans, 2000), which involves overriding of pre-existing proglacial/submarginal moraines. This mechanism is similar to Bouchard's (1989) 'shear and stack' theory for ribbed moraines and is based on field evidence showing glaciotectonic disturbance within the ridges, including folding and thrusting of both sediment and bedrock (Evans and others, 1999, 2008,
2014; Evans, 2000). It is also consistent with their preferential occurrence on the stoss side of higher elevation areas, which would have generated compressive flow at the ice stream bed (Figs 5, 7-12). Evans and others (2008) also noted how some of the ridges were concave in plan form (i.e. with their limbs pointing up-ice) and that this was consistent with them being overridden and deformed/displaced by ice stream activity, although we note that the limbs more commonly point down-ice in our larger sample.

A key question is whether the development of the ridges requires pre-emplacement of proglacial or submarginal moraines that are then overridden, or whether the mere presence of a deformable substrate is sufficient. Their regular wavelength (down-flow) and amplitude in many locations (e.g. Fig. 5), and the lack of any obvious asymmetry on individual ridges (Figs 7,10 ) might imply some form of self-organised pattern that would not necessarily be expected from simply overriding moraines in proglacial or submarginal settings, or the fracturing of pre-existing frozen till sheets (Hättestrand, 1997; Hättestrand and Kleman, 1999). It was partly for this reason that Beaney and Shaw (2000) likened the Milk River examples in southern Alberta (Fig. 10) to fluvial ripple forms, and speculated that the features were 


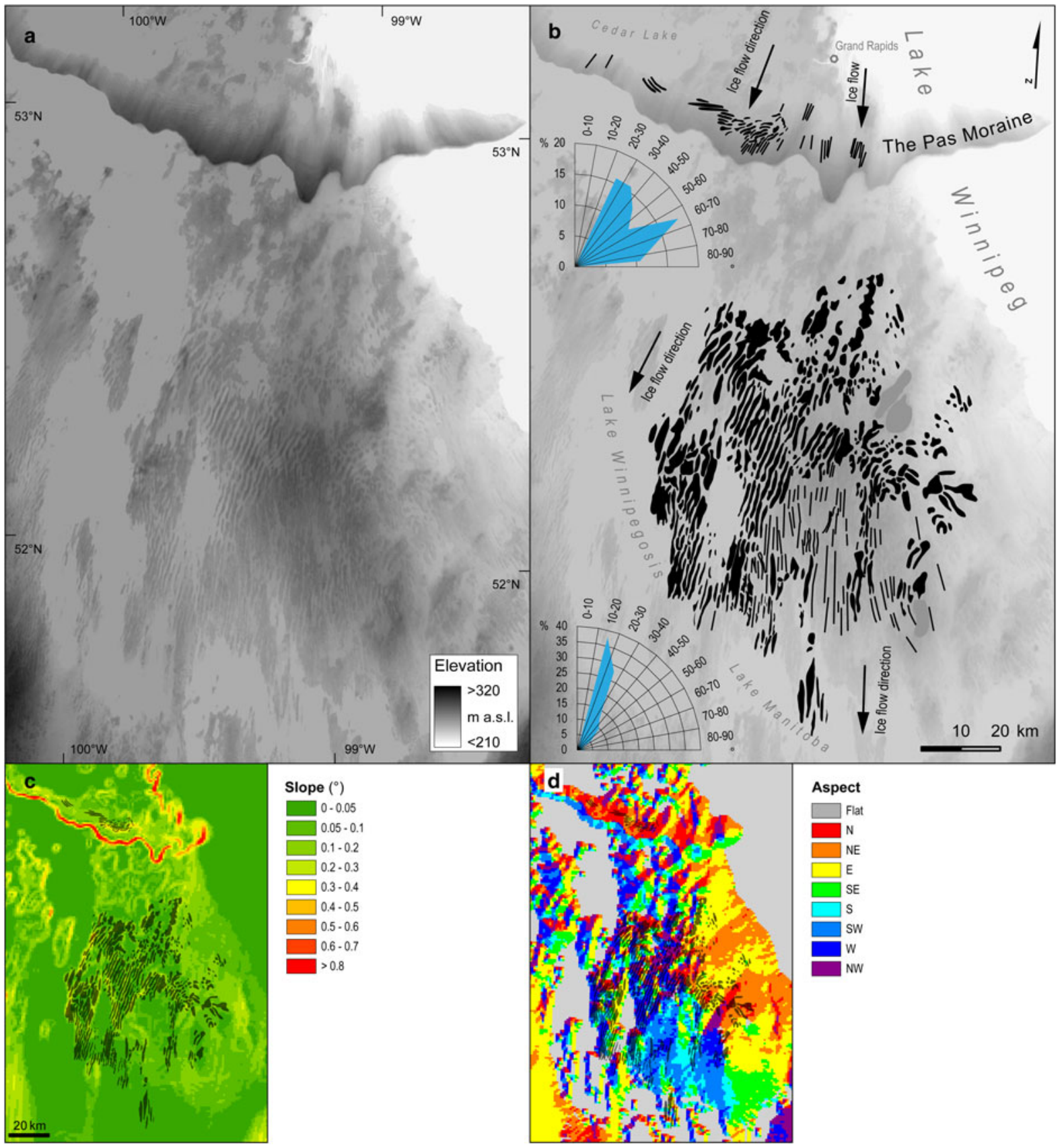

Fig. 12. (a) SRTM DEM of the upstream portion of the Red River Lobe (ice flow from north to south; location shown on Fig. 4). (b) Mapped ribbed features (black shapes), along with the distribution of ridge a-axis deviation from ice flow direction for the two areas. Note the digitate appearance of the Pas moraine (labelled) running west to east towards the top of the image. This moraine was overrun by a later readvance (Dyke and Dredge, 1989), which is likely, based on their superimposition, to have been at the time when the ridges formed. (c), (d) Ribbed features overlain on a slope and aspect map, respectively.

primarily erosional and formed by large subglacial meltwater floods. However, there is no independent evidence for large floods in either the palaeo- or modern-ice stream settings where the ribs are observed, and the volume of water required is deemed implausible (Clarke and others, 2005).

In contrast, Dunlop and others (2008) suggested that ribbed features can be produced by a naturally-arising instability in the coupled flow of ice and till, which has been demonstrated in physically-based numerical modelling (e.g. Hindmarsh, 1998a, b, c; Fowler, 2000; Schoof, 2007; Chapwanya and others, 2011). Significantly, Sergienko and Hindmarsh (2013) demonstrated that similar governing equations that form much smaller and closely-spaced ribbed moraines (Fig. 3) can also produce instabilities that resemble the patterns of traction ribs, for a plausible range of subglacial water and till mixtures. As such, they hypothesised that the basal traction ribs they observed under Pine Island and Thwaites Glaciers might arise from similar dynamic instabilities at the bed of these glaciers, leading to a pattern-forming process that arises from bed strength variations and spatial variations in effective pressure resulting from subglacial water transport. On this basis, traction ribs would only occur in regions where the bed is temperate and till deforms through shearing (Sergienko and Hindmarsh, 2013). The appeal of this instability theory is that the transport of water can be highly variable over short distances leading to localised patches of ridges that we map and their various sizes, potentially including transitions into 


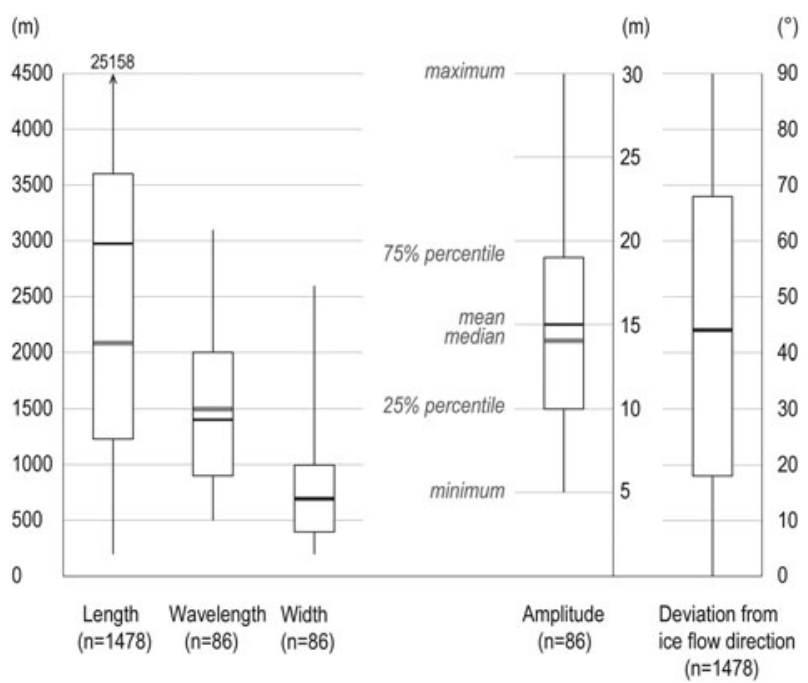

Fig. 13. Box plots summarising the dimensions and orientation of the mapped ridges (see also Tables 1, 2).

linear features that we observe as the subglacial water system evolves (Fowler and Chapwanya, 2014). It is also clear that the growth of the ridges could lead to localised areas of higher effective pressure (cf. Sergienko and Hindmarsh, 2013) that might then induce glaciotectonism (cf. Evans and others, 1999, 2008, 2014; Evans, 2000), particularly on adverse slopes of the ice stream bed.

Related to the above, our slope and aspect analyses point to a tendency for the ribbed bedforms to cluster on adverse slopes where the ice streams flowed over pre-glacial valleys or drainage divides (also Evans and others, 2008, 2014). Given that isostatic loading is not accounted for in our DEM analysis, all bed slopes would have been tipped toward the ice sheet interior (generally towards the northwest) and these adverse slopes would have been higher. Moreover, any subtle overdeepenings associated with these adverse slopes would have acted as subglacial dams, increasing water pressures by causing upstream pressures to rise (Hooke, 1991; Creyts and Clarke, 2010). Depending on the level of connectivity along the adverse slope, effective pressures can turn slightly negative. This causes water to either hydraulically jack (Murray and Clarke, 1995) or fracture the ice/bed interface open (Tsai and Rice, 2010). Water then distributes across the bed until the pressure lowers. Water distribution across the bed helps create broad zones that are in a similar low-strength state that may help explain the lateral dimension of the rib-like features. This increased water pressure will weaken subglacial till, enhancing deformation and potentially leading to a wave like instability.

If overdeepenings are much steeper than the surface slope of the ice sheet by about a factor of two, then glaciohydraulic
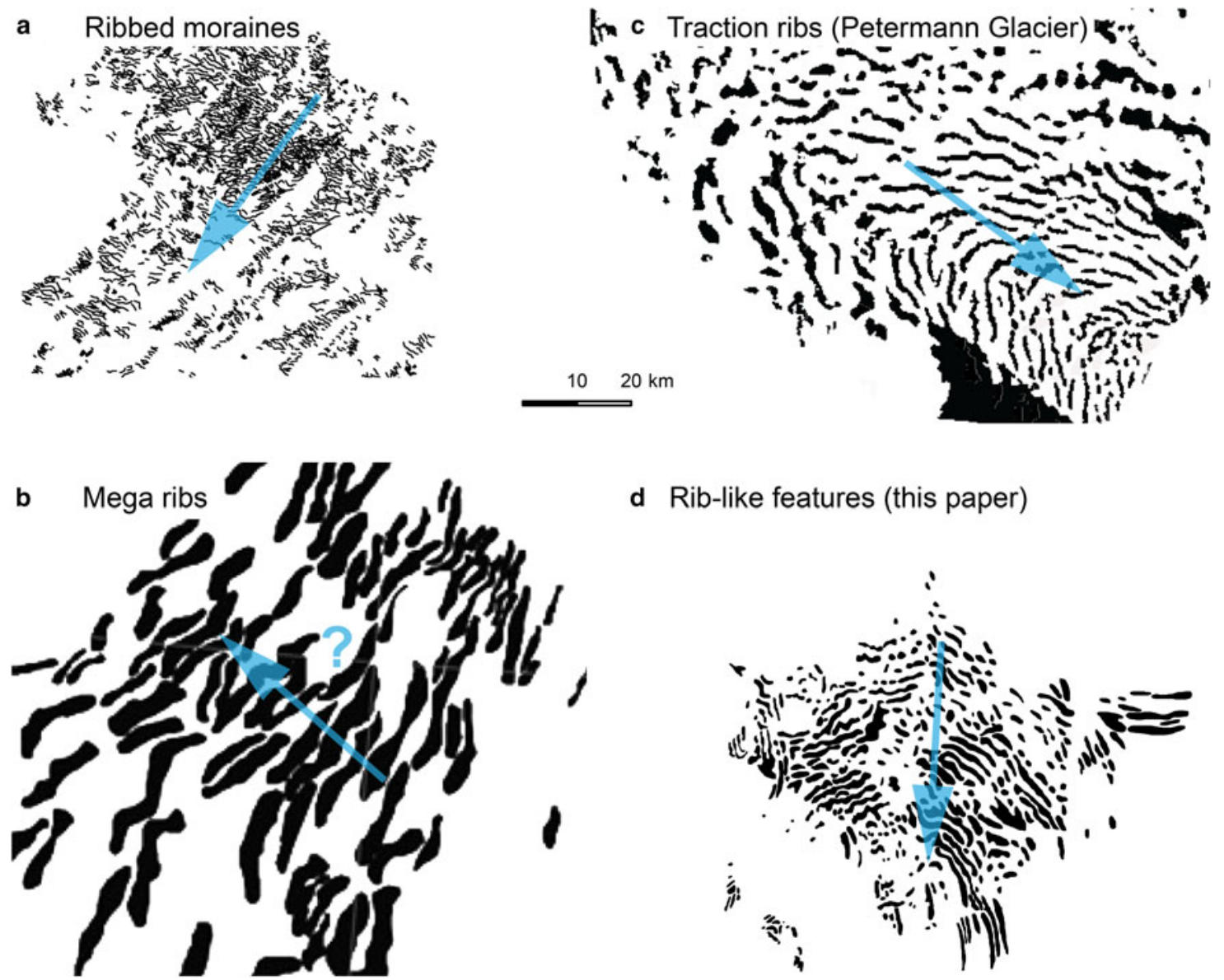

d Rib-like features (this paper)

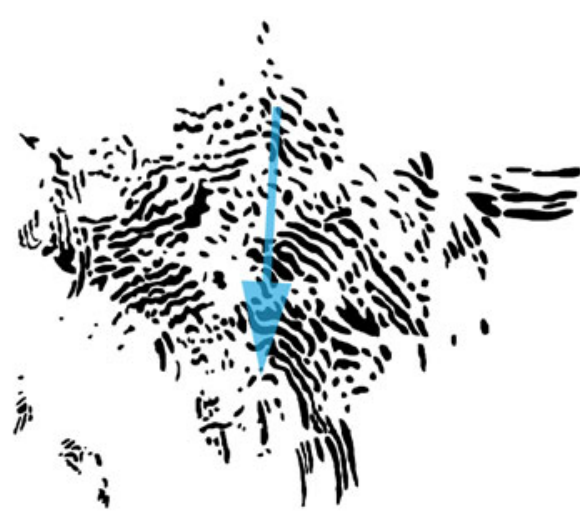

Fig. 14. Scale comparison of the similarity between 'traction ribs' and the ridges we report. (a) Ribbed moraines from the Lac Naococane region of Québec (Fig. 3); mapping from Dunlop and Clark (2006b). (b) Mega-ribs mapped by Greenwood and Kleman (2010) in Keewatin (Fig. 2). (c) Areas of basal shear stress higher than $100 \mathrm{kPa}$ ('traction ribs'; also Fig. 1) modelled under the Petermann Glacier (Greenland) by Sergienko and others (2014). (d) Ridges mapped in this study in the upstream part of the Buffalo Ice Stream corridor (Fig. 5). Ice flow directions are indicated by blue arrows. Note the similarity between (c) and (d). 
supercooling can cause ice formation in the subglacial water system (Röthlisberger and Lang, 1987; Alley and others, 1998). While there is no definitive relationship between bed and surface slope in the areas where ribs are observed, it is likely that many overdeepened areas in our study area meet this slope criterion because ice stream surface slopes tend to be extremely low. The freezing constricts water flow and adds to the overpressure in the hydraulic system (Lawson and others, 1998; Roberts and others, 2002). Observations from numerous glaciers with glaciohydraulic supercooling show high-water pressures as well as high rates of sediment transport. Notably, the rate of change of sediment transport scales with the curvature of the bed (Creyts and others, 2013). Sediment will be deposited, where the bed has high-upward curvature, such as at the onset of overdeepenings. These sediments are then available to be moved up the adverse slope under shear from the overlying ice adding sediment that can be deformed and transported up the slope by the ice sheet.

Thus, we suggest that the two mechanisms, both the instability and glaciotectonism, are potentially linked, but we cautiously conclude that shear instabilities are most compatible with both the regular pattern of landforms that we observe and the patterns inferred from modern ice streams, where overridden moraines are unlikely given the duration of ice-sheet occupation.

\subsection{Implications and future work}

We suggest that there are three main implications of our observations of an intermediate scale of ribbed landforms that overlaps with and bridges the scale of landforms from ribbed moraines to mega-ribs. First and foremost, it implies that the patterns of basal shear stress calculated from control methods (Sergienko and Hindmarsh, 2013; Sergienko and others, 2014) are consistent with a topographic expression seen on palaeo-ice stream beds. Second, our observations provides support for the notion of a subglacial ribbed continuum (Ely and others, 2016) that extends from ribbed moraine (e.g. Hättestrand, 1997; Dunlop and Clark, 2006a, b; Trommelen and others, 2014), through to intermediate-scale 'traction ribs' (Sergienko and Hindmarsh, 2013; Sergienko and others, 2014; this paper), and upward to the much larger mega-ribs (Greenwood and Kleman, 2010). The overlapping pattern and dimensions of these features suggests a continuum of ribbed bedforms of different sizes that could be genetically-related, and that different names need not imply different formative mechanisms (ribbed moraine, traction ribs, mega-ribs), although each, potentially, exhibits a different wave-length relative to ice thickness. A third important implication is that ribbed landforms are not necessarily associated with low ice velocities. While ribbed moraines are abundant on former ice-sheet beds and tend to occur in core areas, close to ice divides, where there may be changes in basal thermal regime (Hättestrand, 1997; Hättestrand and Kleman, 1999; Kleman and Hättestrand, 1999), the ribbed landforms we report here are typically associated with higher ice velocities, adverse slopes and the presence of warm-based ice. Coupled with observations from modern-ice streams (Sergienko and Hindmarsh, 2013; Sergienko and others, 2014), this suggests that ribbed landforms can form localised patches of higher basal friction within fast-flowing sectors of ice sheets and that this may play an important role in modulating resistance in the interior of the ice stream and their total ice discharge (Sergienko and Hindmarsh, 2013). A similar conclusion was reached by Trommelen and others (2014) who suggested that ribbed moraines in Manitoba may be associated with increased bed stickiness, perhaps associated with dewatered subglacial sediments.

Given the apparent ubiquity of traction-ribs under modern ice masses (Sergienko and others, 2014), one might wonder why they have not been reported more widely from palaeo-ice sheet beds. One possibility is that they are common, but observational techniques have been unable to detect them. They clearly require DEMs of sufficient resolution. While previous workers using the 3 arcsec SRTM data had reported their existence in the southern Interior Plains (Evans and others, 1999, 2008, 2014; Evans, 2000; Ross and other, 2009; Ó Cofaigh and others, 2010), they did not map the detailed morphometry and pattern. The 1 arcsec SRTM data in this study has enabled more detailed mapping. Given that similar and higher resolution DEMs are now commonly used to map glacial geomorphology on palaeo-ice sheet beds (Hughes and others, 2010; Dowling and others, 2015), we suggest that observational techniques/bias might have allowed some features to remain undetected, but this is unlikely to explain their apparent scarcity.

Thus, another possibility is that they are actually quite rare and only generated in specific settings. Observations from the Interior Plains clearly show that their occurrence is patchy, which suggests that they require specific conditions to form that only exist in some regions of the ice-sheet bed. This occurrence is consistent with the notion that traction ribs should only occur in regions where the strength of a till that is sheared is determined by a subglacial water system (Sergienko and Hindmarsh, 2013). However, post-glacial drainage can erode soft sediments so that they are not preserved. Moreover, if the traction ribs in Antarctica and Greenland (Sergienko and Hindmarsh, 2013; Sergienko and others, 2014) are due as well (or sometimes instead) of transverse undulations in water pressure without coupling to till, this might also explain their relative scarcity in the topography of palaeo-ice sheet beds. Furthermore, they appear to require softer sedimentary bedrock and a sufficient till cover (Fig. 6), but large areas of the Laurentide and Eurasian ice sheet beds are dominated by crystalline bedrock. Related to this possible geological control, it might also be the case that even when they do form, they are only rarely preserved. Sergienko and Hindmarsh (2013) noted that the numerically modelled growth of the features is of the order of decades to centuries and that the basal resistance offered by traction ribs could change over these timescales in response to changes in ice sheet geometry or subglacial hydrology. Thus, there may be some process that acts to remove traction ribs from the ice-sheet bed prior to deglaciation and/or that they commonly transition into other landforms (such as glacial lineations; Ely and others, 2016). It may be, for example, that many ridges are 'drumlinised' by late-glacial ice stream activity.

Clearly, future work could attempt to systematically search for and map traction ribs on palaeo-ice sheet beds to resolve some of these issues. In addition, it should be possible to detect them beneath modern ice masses using highresolution geophysical techniques (e.g. radar; King and others, 2009). Detailed field investigation of the traction ribs reported in this paper may also be able to further 
constrain their mode of formation (e.g. geophysical surveys and sedimentological analyses) and examine the prevalence of glaciotectonism and whether it took place during or after ridge formation.

\section{CONCLUSIONS}

Recent work using standard inverse techniques has highlighted a previously-unrecognised pattern of basal shear stress beneath modern ice masses, particularly in areas of ice streaming (Sergienko and Hindmarsh, 2013; Sergienko and others, 2014). These are characterised by regular riblike patterns of very high basal shear stress (>200 kPa) embedded within much larger areas of near-zero basal shear stress in regions where ice was assumed to be sliding across the bed. They have been termed 'traction ribs' (Sergienko and Hindmarsh, 2013) and their pattern resembles rib-like features observed on palaeo-ice sheet beds. However, they occur at a scale that is intermediate between smaller and more closely-spaced ribbed moraines and much larger mega-ribs (Greenwood and Kleman, 2010). Furthermore, it is not known whether they are caused by variations in topography that cause 'stickiness', or whether they are simply stickier areas within an otherwise flat bed, e.g. undulations in water pressure.

In this paper, we report observations of similar features from the now-exposed bed of the Laurentide ice sheet. We used DEMs to map $>1000$ rib-like features on four previously-identified palaeo-ice streams from the Interior Plains of Western Canada (Evans and others, 1999, 2008, 2014; Evans, 2000; Ross and other, 2009; Ó Cofaigh and others, 2010). Measurements of their length, width, spacing and amplitude indicate that they resemble the traction ribs inferred from beneath modern ice masses. We therefore suggest the traction ribs inferred from beneath modern-ice masses might have a topographic expression, and that their identification implies a continuum of ribbed landforms from smaller, closely spaced ribbed moraines, through traction ribs and up to the much larger mega-ribs (Ely and others, 2016). To date, there is little consensus as to the mechanisms of formation of ribbed features in subglacial environments but our observations, coupled with those from modern ice masses, suggest that the instability theory (Dunlop and others, 2008; Chapwanya and others, 2011; Fowler and Chapwanya, 2014) - invoking the growth of ribs as a result of a naturally-arising instability in the coupled flow of ice and till (and/or subglacial water) - is most compatible with their form and pattern, perhaps also involving glaciotectonic thrusting of subglacial material (Evans and others, 1999, 2008, 2014; Evans, 2000).

\section{ACKNOWLEDGEMENTS}

This research was funded by a Natural Environment Research Council grant (NE/J00782X/1). We thank Martin Ross and Michelle Trommelen for their constructive reviews and the Scientific Editor, Neil Glasser and Editor-in-Chief, Jo Jacka. We also thank Dave Evans, Richard Hindmarsh and Olga Sergienko for useful discussions.

\section{REFERENCES}

Alley RB (1993) In search of ice stream sticky spots. J. Glaciol, 39 (133), 447-454
Alley RB, Anandakrishnan S, Bentley CR and Lord N (1994) A waterpiracy hypothesis for the stagnation of ice stream C, Antarctica. Ann. Glaciol., 20, 187-194

Alley RB, Lawson DE, Evenson EB, Strasser JC and Larson GJ (1998) Glaciohydraulic supercooling: a freeze-on mechanism to create stratified, debris-rich basal ice: II. Theory. J. Glaciol., 44(148), 563-569

Anandakrishnan S and Alley RB (1994) Ice Steam C, Antarctica, sticky spots detected by microearthquake monitoring. Ann. Glaciol., 20, 183-186

Anandakrishnan S and Alley RB (1997) Stagnation of ice stream C, West Antarctica by water piracy. Geophy. Res. Lett., 24(3), 265-268

Ashmore DW, Bingham RG, Hindmarsh RCA, Corr HFJ and Joughin I (2014) The relationship between sticky spots and radar reflectivity beneath an active West Antarctic ice stream. Ann. Glaciol., 55(67), 29-38

Atkinson N, Utting DJ and Pawley SM (2014) Glacial landforms of Alberta. Alberta Energy Regulator, Edmonton, AER/AGS Map 604, scale 1:1000 000

Atre SR and Bentley CR (1993) Laterally varying basal conditions beneath ice streams B and C, West Antarctica. J. Glaciol., 39 (133), 507-514

Aylsworth JA and Shilts WW (1989) Bedforms of the Keewatin Ice Divide, Canada. Sed. Geol., 62, 407-428

Bamber JL, Vaughan DG and Joughin I (2000) Widespread complex flow in the interior of the Antarctic ice sheet. Science, 287(5456), 1248-1250

Beaney CL and Shaw J (2000) The subglacial geomorphology of southeast Alberta: evidence for subglacial meltwater erosion. Can. J. Earth Sci., 37, 51-67

Bennett MR (2003) Ice streams as the arteries of an ice sheet: their mechanics, stability and significance. Earth-Sci. Rev., 61, 309-339

Bentley CR (1987) Antarctic ice streams: a review. J. Geophys. Res., 92(B9), 8843-8858

Bindschadler RA, Stephenson SN, MacAyeal DR and Shabtaie S (1987) Ice dynamics at the mouth of ice stream B, Antarctica. J. Geophys. Res., 92(B9), 8885-8894

Bouchard M (1989) Subglacial landforms and deposits in central and northern Québec, Canada, with emphasis on Rogen moraines. Sed. Geol., 62, 293-308

Bougamont M, Tulaczyk S and Joughin I (2003a) Response of subglacial sediments to basal frezze-on: 2 . Application in numerical modelling of the recent stoppage of ice stream C, West Antarctica. J. Geophys. Res., 108(B4), 20.1-20.16

Bougamont M, Tulaczyk S and Joughin I (2003b) Numerical investigations of the slow-down of Whillans Ice Stream, West Antarctica: is it shutting down like ice stream C? Ann. Glaciol., 37, 239-246

Boulton GS (1987) A theory of drumlin formation by subglacial deformation. In Menzies J and Rose J eds. Drumlin symposium. Balkema, Rotterdam, 25-80

Chapwanya M, Clark CD and Fowler AC (2011) Numerical computations of a theoretical model of ribbed moraine formation. Earth Surf. Proc. Land., 36, 1105-1112

Christoffersen P and Tulaczyk S (2003a) Thermodynamics of basal freeze-on: predicting basal and subglacial signatures of stopped ice streams and interstream ridges. Ann. Glaciol., 36, 233-243

Christoffersen P and Tulaczyk S (2003b) Response of subglacial sediments to basal freeze-on: 1 . Theory and comparison to observations from beneath the west Antarctic ice sheet. J. Geophys. Res., 108(B4), 19.1-19.16

Christoffersen P and Tulaczyk S (2003c) Signature of palaeo-ice stream stagnation: till consolidation induced by basal freezeon. Boreas, 32, 114-129

Clark CD and Stokes CR (2001) Extent and basal characteristics of the $\mathrm{M}^{\prime}$ Cintock channel ice stream. Quat. Int., 86, 81-101

Clark PU (1992) Surface form of the southern Laurentide ice sheet and its implications to ice-sheet dynamics. Geol. Soc. Am. Bull., 104, 595-605 
Clarke GKC (1987) Fast glacier flow: ice streams, surging, tidewater glaciers. J. Geophys. Res., 92(B9), 8835-8841

Clarke GKC, Leverington DW, Teller JT, Dyke AS and Marshall SJ (2005) Fresh arguments against the Shaw megaflood hypothesis. Quat. Sci. Rev., 24, 1533-1541

Clayton L, Teller JT and Attig JW (1985) Surging of the southwestern part of the Laurentide ice sheet. Boreas, 14, 235-241

Creyts TT and Clarke GKC (2010) Hydraulics of subglacial supercooling: theory and simulations for clear water flows. J. Geophys. Res., 115, F03021

Creyts TT, Clarke GKC and Church M (2013) Evolution of subglacial overdeepenings in response to sediment redistribution and glaciohydraulic supercooling. J. Geophys. Res., 118, 423-446

Dowling TPF, Spagnolo M and Möller P (2015) Morphometry and core type of streamlined bedforms in southern Sweden from high resolution LiDAR. Geomorphology, 236, 54-63

Dunlop P and Clark CD (2006a) The morphological characteristics of ribbed moraine. Quat. Sci. Rev., 25, 1668-1691

Dunlop P and Clark CD (2006b) Distribution of ribbed moraine in the Lac Naococane region, central Québec, Canada. J. Maps, 2 (1), 59-70

Dunlop P, Clark CD and Hindmarsh RCA (2008) The Bed Ribbing Instability Explanation (BRIE) - testing a numerical model of ribbed moraine formation arising from the coupled flow of ice and subglacial sediment. J. Geophys. Res., 113, F03005 (doi: 10.1029/2007JF000954)

Dyke AS and Dredge LA (1989) Quaternary geology of the northwestern Canadian Shield. In Fulton RJ ed. Quaternary geology of Canada and Greenland. Geological Survey of Canada, Ottawa, 189-214

Dyke AS and Morris TF (1988) Drumlin fields, dispersal trains, and ice streams in Arctic Canada. Can. Geog., 32, 86-90

Dyke AS, Morris TF, Green DEC and England J (1992) Quaternary geology of Prince pf Wales Island, Arctic Canada. In Geological survey of Canada Memoir, vol. 433. Ottawa, Canada

Ely JC and 7 others (2016) Do subglacial landforms comprise a size and shape continuum? Geomorphology, 257, 108-119

Evans DJA (2000) Quaternary geology and geomorphology of the Dinosaur Provincial Park area and surrounding plains, Alberta, Canada: the identification of former glacial lobes, drainage diversions and meltwater flood tracks. Quat. Sci. Rev., 19, 931-958

Evans DJA, Lemmen DS and Rea BR (1999) Glacial landsystems of the southwest Laurentide ice sheet: modern Icelandic analogues. J. Quat. Sci., 14(7), 673-691

Evans DJA, Clark CD and Rea BR (2008) Landform and sediment imprints of fast glacier flow in the southwest Laurentide ice sheet. J. Quat. Sci., 46, 80-125

Evans DJA and 5 others (2012) Till stratigraphy and sedimentology at the margins of terrestrially terminating ice streams: case study of the western Canadian prairies and high plains. Quat. Sci. Rev., 46, 80-125

Evans DJA, Young NJP and Ó Cofaigh C (2014) Glacial geomorphology of terrestrially-terminating fast flow lobes/ice stream margins in the southwest Laurentide ice sheet. Geomorphology, 204, 86-113

Fenton MM, Schreiner BT, Nielsen E and Pawlowicz JG (1994) Quaternary geology of the Western Plains. In Mossop GD and Shetsen I eds. Geological Atlas of the Western Canada Sedimentary Basin. Canadian Society of Petroleum Geologists and Alberta Research Council, Edmonton, Special Report 4, 413-420

Fisher TG and Shaw J (1992) A depositional model for Rogen moraine, with examples from the Avalon Peninsula, Newfoundland. Can. J. Earth Sci., 29, 669-686

Fowler AC (2000) An instability mechanism for drumlin formation. In Maltman A, Hambrey MJ and Hubbard B eds. Deformation of glacial materials. Geological Society of America, Boulder, Colorado, USA, 307-319

Fowler AC and Chapwanya M (2014) An instability theory for the formation of ribbed moraine, drumlins and mega-scale glacial lineations. Proc. Roy. Soc., A, 470, 20140185
Garrity CP and Soller DR (2009) Database of the Geologic Map of North America; adapted from the map by J.C. Reed, Jr. and others (2005): U.S. Geological Survey Data Series 424. http:// pubs.usgs.gov/ds/424/

Geological Survey of Canada (2014) Surficial geology of Canada. Geological Survey of Canada, Ottawa, Canadian Geoscience Map 195 (preliminary, Surficial Data Model v. 2.0 conversion of Map1880A), scale 1:5 000000 (doi: 10.4095/295462)

Graham AGC and 5 others (2009) Bedform signature of a west Antarctic palaeo-ice stream reveals a multi-temporal record of flow and substrate control. Quat. Sci. Rev., 28, 2774-2793

Greenwood SL and Kleman J (2010) Glacial landforms of extreme size I the Keewatin sector of the Laurentide ice sheet. Quat. Sci.Rev., 29, 1894-1910

Hättestrand C (1997) Ribbed moraines in Sweden - distribution pattern and palaeoglaciological significance. Sed. Geol., 111 $41-56$

Hättestrand C and Kleman J (1999) Ribbed moraine formation. Quat. Sci. Rev., 18, 43-61

Hindmarsh RCA (1998a) The stability of a viscous till sheet coupled with ice flow, considered at wavelengths less than the ice thickness. J. Glaciol., 44(147), 285-292

Hindmarsh RCA (1998b) Drumlinisation and drumlin-forming instabilities: viscous till mechanisms. J. Glaciol., 44, 589-614

Hindmarsh RCA (1998c) Ice stream surface texture, sticky spots, waves and breathers: the coupled flow of ice, till and water. J. Glaciol., 44, 589-614

Hooke RL (1991) Positive feedbacks associated with erosion of glacial cirques and overdeepenings. Geol. Soc. Am. Bull., 103 (8), 1104-1108

Hughes ALC, Clark CD and Jordan CJ (2010) Subglacial bedforms of the last British ice sheet. J. Maps, 6(1), 543-563

Joughin I, MacAyeal DR and Tulaczyk S (2004) Basal shear stress of the Ross ice streams from control method inversions. J. Geophys. Res., 109, B09405 (doi: 10.1029/2003JB002960)

King EC, Hindmarsh RCA and Stokes CR (2009) Formation of megascale glacial lineations observed beneath a West Antarctic ice stream. Nat. Geosci., 2(8), 529-596

Kleman J and Hättestrand C (1999) Frozen-bed Fennoscandian and Laurentide ice sheets during the Last Glacial Maximum. Nature, 402, 63-66

Knight J (2002) Glacial sedimentary evidence supporting stick-slip basal ice flow. Quat. Sci. Rev., 21, 975-983

Lawson DE and 5 others (1998) Glaciohydraulic supercooling: a freeze-on mechanism to create stratified, debris-rich basal ice: I. Field evidence. J. Glaciol., 44(148), 547-562

Lesemann J-E, Piotrowski JA and Wysota W (2010) "Glacial curvilineations": new glacial landforms produced by longitudinal vortices in subglacial meltwater flows. Geomorphology, 120, 153-161

Lundqvist J (1989) Rogen (ribbed) moraine: identification and possible origin. Sed. Geol., 62, 281-292

Lundqvist J (1997) Rogen moraine - an example of two-step formation of glacial landscapes. Sed. Geol., 111, 27-40

MacAyeal DR (1992) The basal stress-distribution of ice stream $E$ Antarctica, inferred from control methods. J. Geophys. Res., 97 (B1), 595-603

MacAyeal DR, Bindschadler RA and Scambos TA (1995) Basal friction of ice stream E, west Antarctica. J. Glaciol., 5(41), 661-603

Margold M, Stokes CR, Clark CD and Kleman J (2015a) Ice streams in the Laurentide ice sheet: a new mapping inventory. J. Maps, 11 (3), 380-395

Margold M, Stokes CR and Clark CD (2015b) Ice streams in the Laurentide ice sheet: identification, characteristics and comparison to modern ice sheets. Earth-Sci. Rev., 143, 117-146

Möller P (2006) Rogen moraine - an example of glacial reshaping of pre-existing landforms. Quat. Sci. Rev., 25, 362-389

Murray T and Clarke GKC (1995) Black-box modeling of the subglacial water system. J. Geophys. Res., 100(B7), 10231-10245

$\mathrm{Ng}$ FSL (2015) Spatial complexity of ice flow across the Antarctic ice sheet. Nat. Geosci., 8(11), 847-850 
Ó Cofaigh C, Evans DJA and Smith IR (2010) Large-scale reorganisation and sedimentation of terrestrial ice streams during late Wisconsinan Laurentide ice sheet deglaciation. Geol. Soc. Am., Bull., 122(5-6), 743-756

Patterson CJ (1997) Southern Laurentide ice lobes were created by ice streams: Des Moines lobe in Minnesota, USA. Sed. Geol., 111, 249-261

Piotrowski JA, Larsen NK and Junge FW (2004) Reflections on soft subglacial beds as a mosaic of deforming and stable spots. Quat. Sci. Rev., 23, 883-1000

Rignot E, Mouginot J and Scheuchl B (2011) Ice flow of the Antarctic ice sheet. Science, 333, 1247-1430

Roberts MJ and 7 others (2002) Glaciohydraulic supercooling in Iceland. Geology, 30(5), 439-442

Rooney ST, Blankenship DD, Alley RB and Bentley CR (1987) Till beneath ice stream B 2. Structure and continuity. J. Geophys. Res., 92(B9), 8913-8920

Ross M, Campbell JE, Parent M and Adams RS (2009) Palaeo-ice streams and the subglacial landscape mosaic of the North American mid-continental prairies. Boreas, 38(3), 421-439

Röthlisberger H and Lang H (1987) Glacio-fluvial sediment transfer: an alpine perspective. In Gurnell AM and Clark MJ eds. Glacial hydrology. John Wiley and Sons, New York, 207-284

Schoof C (2007) Pressure-dependent viscosity and interfacial instability in coupled ice-sediment flow. J. Fluid Mech., 570 227-252

Sergienko OV and Hindmarsh RCA (2013) Regular patterns in frictional resistance of ice-stream beds seen by surface data inversion. Science, 342, 1086-1089

Sergienko OV, Creyts TT and Hindmarsh RCA (2014) Similarity of organised patterns in driving and basal shear stresses of Antarctic and Greenland ice sheets beneath extensive areas of basal sliding. Geophys. Res. Lett., 41 (doi: 10.1002/2014GL059976)

Shaw J (1979) Genesis of the Sveg till and Rogen moraines of central Sweden: a model of basal melt out. Boreas, 8, 409-426
Smith AM (1997) Variations in basal conditions on Rutford ice stream, West Antarctica. J. Glaciol., 43(144), 245-255

Spagnolo M and 7 others (2014) Size, shape and spatial arrangement of mega-scale glacial lineations from a large and diverse dataset. Earth Surf. Proc. Land., 39, 1432-1448

SRTM (2015). Shuttle Radar Topographic Mission. http://viewer. nationalmap.gov/ (last accessed 30 June 2015)

Stokes CR and Clark CD (2003) The Dubawnt Lake palaeo-ice stream: evidence for dynamic ice sheet behaviour on the Canadian Shield and insights regarding the controls on ice stream location and vigour. Boreas, 32, 263-279

Stokes CR, Clark CD, Lian OB and Tulaczyk S (2007) Ice stream sticky spots: a review of their identification and influence beneath contemporary and palaeo-ice streams. Earth-Sci. Rev., 81, 217-249

Stokes CR, Lian OB, Tulaczyk S and Clark CD (2008) Superimposition of ribbed moraines on a palaeo-ice stream bed: implications for ice stream dynamics and shutdown. Earth Surf. Proc. Land., 33, 593-609

Stokes CR, Margold M, Clark CD and Tarasov L (2016) Ice stream activity scaled to ice sheet volume during Laurentide ice sheet deglaciation. Nature, 530, 322-326

Trommelen MS and Ross M (2014) Distribution and type of sticky spots at the centre of a deglacial streamlined lobe in northeastern Manitoba, Canada. Boreas, 43(3), 557-576

Trommelen MS, Ross M and Ismail A (2014) Ribbed moraines in northern Manitoba, Canada: characteristics and preservation as part of a subglacial bed mosaic near the core regions of ice sheets. Quat. Sci. Rev., 87, 135-155

Tsai VC and Rice JR (2010) A model for turbulent hydraulic fracture and application to crack propagation at glacier beds. J. Geophys. Res., 115 (doi: 10.1029/2009JF001474)

Vornberger PL and Whillans IM (1986) Surface features of ice stream B, Marie Byrd Land, West Antarctica. Ann. Glaciol., 8, $168-170$

MS received 17 December 2015 and accepted in revised form 4 April 2016; first published online 10 May 2016 